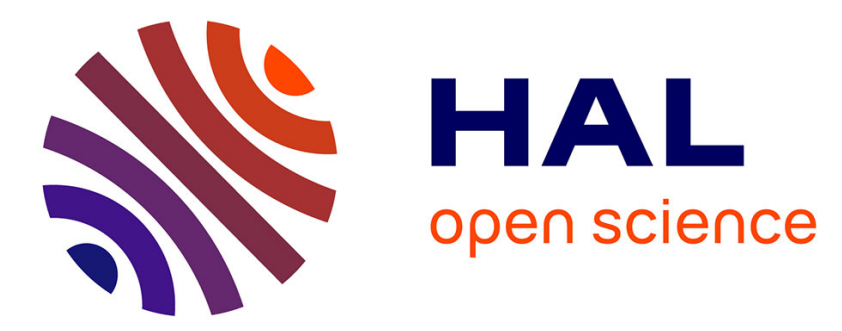

\title{
Ligand effects on coordination properties of organolithium compounds: insights from computational experiments on a "weakened" $\mathrm{Li}+$
}

Hélène Gérard, Patrick Chaquin, Jacques Maddaluno

\section{- To cite this version:}

Hélène Gérard, Patrick Chaquin, Jacques Maddaluno. Ligand effects on coordination properties of organolithium compounds: insights from computational experiments on a "weakened" Li+. Journal of Molecular Graphics and Modelling, 2019, 26 (3), pp.59. 10.1007/s00894-020-4302-2 . hal-03439676

\author{
HAL Id: hal-03439676 \\ https://hal.science/hal-03439676
}

Submitted on 22 Nov 2021

HAL is a multi-disciplinary open access archive for the deposit and dissemination of scientific research documents, whether they are published or not. The documents may come from teaching and research institutions in France or abroad, or from public or private research centers.
L'archive ouverte pluridisciplinaire HAL, est destinée au dépôt et à la diffusion de documents scientifiques de niveau recherche, publiés ou non, émanant des établissements d'enseignement et de recherche français ou étrangers, des laboratoires publics ou privés. 


\section{Journal of Molecular Modeling \\ Ligand effects on coordination properties of organolithium compounds: insights from computational experiments on a "weakened" $\mathrm{Li}+$ \\ --Manuscript Draft--}

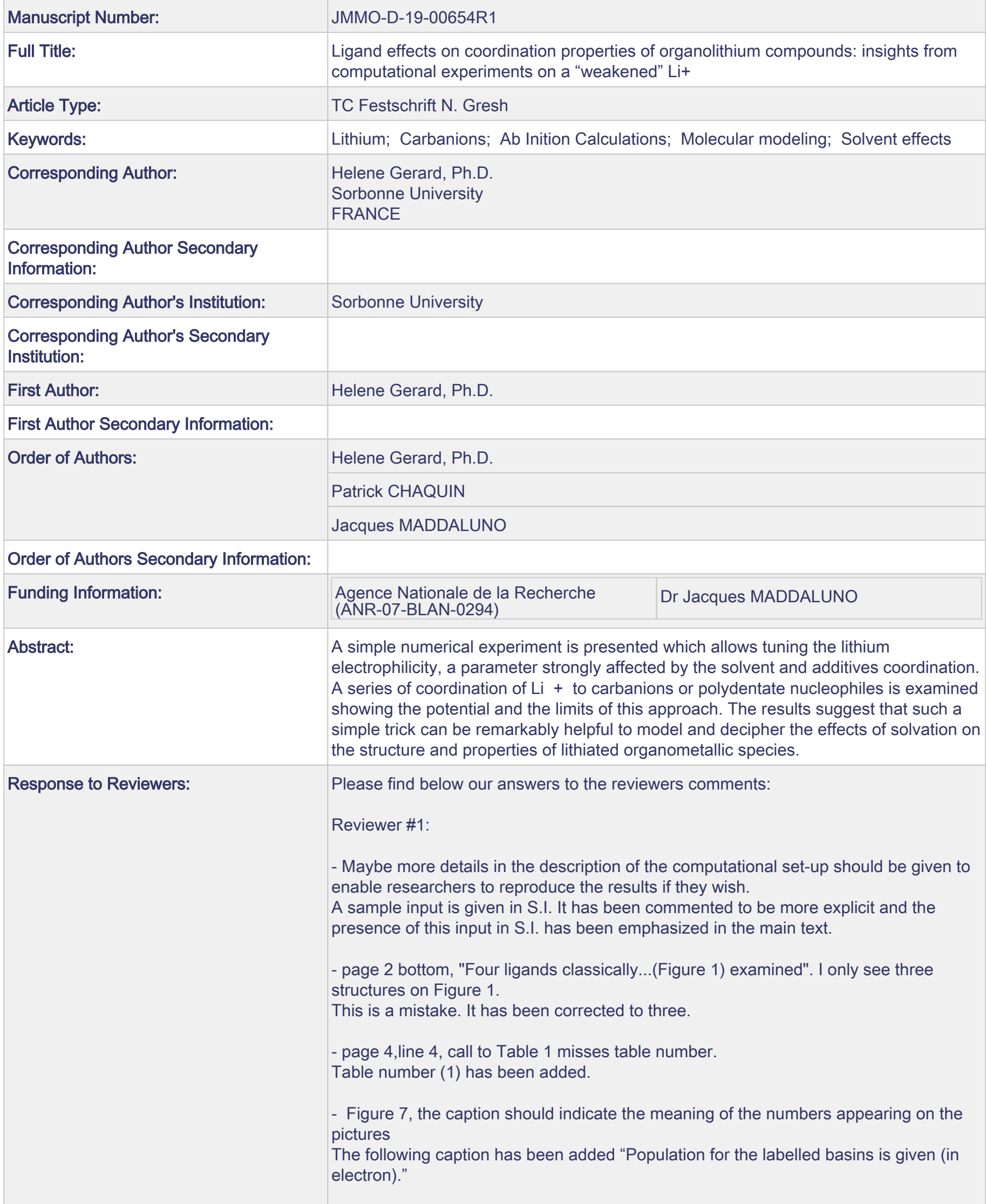


- Most Figures showing graphs should be redrawn more (with bigger label fonts, with Ticks).

Figure 3, 4 and 5 have been redrawn. A xls file including necessary data for plotting the graph can be provided to editorial office upon request.

\section{Reviewer \#2:}

On page 4, the table number is missing " on the Li center are reported in Table ." Table number (1) has been added.

On page 6, there is a typo : "Li-C bond rises from $1.985 \mathrm{~A}$ is absence of coordination", I suppose the authors mean "in absence".

This is right and has been corrected in that way.

Can the authors confirm that the energy difference they give are potential energies and not Gibbs Free energies?

This has been added in the text (page 9) and in the legend of figure 6 .

In the first section, the authors discuss the evolution of $\mathrm{Li}+$ orbital energies in different systems, can the authors give that of the neutral Li for comparison ? I also suggest to give the energies in Table 1 in eV for simplicity.

This has been done. The values in Table 1 are now in $\mathrm{eV}$ and the orbital energies are now given for $\left.\mathrm{Li}_{\mathrm{Li}} \mathrm{Li}^{*} \mathrm{c}=0.1\right)$ and $\mathrm{Li}^{*}(\mathrm{c}=-0.1)$ for complete information.

In the second section, the authors discuss the geometry evolution of Li-allyl complex upon coordination of neutral molecules. Would it be possible to perform Energy Decomposition Analysis and try to make a link between the donation and electrostatic values with the parameter of equation 2 ?

Natural population analysis shows a significantly stronger donation toward $\mathrm{Li}$ in the terminal structure compared to the bridged one (for $\mathrm{c}=0.02,0.18$ and $0.03 \mathrm{e}$ population of the $2 \mathrm{~s} \mathrm{Li}$ orbital are found respectively). This sentence has been added page 10 . Carrying out a complete Energy Decomposition Analysis would require adapting the $\mathrm{Li}^{*}$ method to a new software, which cannot be carried out in the time frame offered for the revisions.

Could the authors precise how evolves the $\mathrm{C}$ - $\mathrm{C}$ bond the allylic anion in the terminal structure?

A closer look at the terminally bonded structures reveals a dissymmetry in the C-C distance, the Li-bonded $\mathrm{C}=\mathrm{C}$ being $0.12 \AA$ longer than the other one, whatever the value of $\mathrm{c}$. This sentence has been added page 9.

Do the two bassins still are similar or do they differ significantly?

This is associated to a polarization of the electron density on the Li bonded side (total population on Li bonded side equal to $3.90 \mathrm{e}$ compared to $3.53 \mathrm{e}$ on the other one). This sentence has been added page 10 and Figure 7 has been modified to add the necessary values for the discussion.

The authors have take $\mathrm{OMe} 2$ as an archetype of etheral solvents but they also showed that the structure is strongly dependent to the donation from the ligand. THF is known to be slightly more basic than of ether. Does the authors expect a transition to a terminal structure sooner with THF than in $\mathrm{OMe} 2$ ?

Computation of a scan with three THF molecules was too time-consuming to be carried out with the time frame offered for the revisions. Nevertheless, coordination of the third solvent molecule was used to probe the effect of strong donation. Coordination of three ether molecules to allyl is in fact a slightly higher coordination number than what would be expected from experimental data 


\section{Ligand effects on coordination properties of}

\section{organolithium compounds: insights from computational}

\section{experiments on a "weakened" $\mathrm{Li}^{+}$}

Hélène GERARD ${ }^{1}$, Patrick CHAQUIN ${ }^{1}$ and Jacques MADDALUNO²

1: Sorbonne Université, CNRS, Laboratoire de Chimie Théorique, LCT, F-75005 Paris, France. helene.gerard@sorbonne-universite.fr ; Tel : (+33) 144279662

2 : Normandie Univ, UNIROUEN, INSA Rouen, CNRS, COBRA, (UMR 6014 \& FR 3038), F-76000, Rouen, France

Summary: A simple numerical experiment is presented which allows tuning the lithium electrophilicity, a parameter strongly affected by the solvent and additives coordination. A series of coordination of $\mathrm{Li}^{+}$to carbanions or polydentate nucleophiles is examined showing the potential and the limits of this approach. The results suggest that such a simple trick can be remarkably helpful to model and decipher the effects of solvation on the structure and properties of lithiated organometallic species.

Keywords : Lithium; Carbanions ; An initio calculations ; Molecular Modeling ; Solvent effects 


\section{Introduction}

The computational description of lithiated organometallic species, Li being either the organometallic center or being associated to other metal cations ( $\mathrm{Al}, \mathrm{Cu}, \mathrm{Zn} . .$.$) , is particularly challenging.$ Experimentally, these reagents are used in complex media[1] of which realistic models should include all substituants to provide a meaningful representation of the metal center and counter ion coordination spheres, namely ligands, potential chelating additives and explicit solvant molecules.[2] The versatility of the $\mathrm{Li}^{+}$coordination, strongly depending on an operational accounting of these effects, requires an heavy modelling procedure. Indeed, neglecting their effect introduces a stern flaw in the model as it strongly alters the spatial location of the lithium ion, which is known to change, in turn, the chemo, regio and stereochemical courses of the reactions[3-5]. Eventhough explicit representation of these additional ligands rises steeply the computational cost of the study, the ever rising computational power associated to latest development in modelling methods allows such approaches.[6] Nevertheless, studies remain hindered by the complexity of the system in term of degrees of freedom, which requires paying particular attention to conformational and configurational sampling. It also dramatically alters the lisibility of the resulting structures, limiting the interpretative power of computational approaches.

Would it be possible to computationally reproduce the electronic effects triggered by the agents and solvents coordinating Li without introducing their structural complexity? With the exception of early models resorting to point charges [7-8], no such approach has been developped for lithium coordination to our knowledge. Inspired by the efforts made to rationalize various substituents effects in organic molecules, and in particular the $\mathrm{H}^{*}$ method [9], developed by one of us, we decided to tackle this problem. $\mathrm{H}^{*}$ is a computational tool which proved efficient in deciphering the respective role of inductive or mesomer effects of subsituants in organic reactions [10-12]. A similar tool was next used to modulate the binding potential of a Lewis base, and gauge the impact of the apical ligand basicity on the chemical reactivity of tetradentate $\mathrm{Cu}$-amine complexes.[13]

In this study, we aim at understanding how ligands binding influences the Lewis acidity of the Li center and, as a consequence, the behavior of various organolithium compounds. Three ligands classically 
encountered in organolithium chemistry (Figure 1) are examined. $\mathrm{Me}_{2} \mathrm{O}$ is introduced as a simplified model for monocoordinated ligands, and especially for the usual coordinating ethereal solvent, such as diethylether or tetrahydrofuran.[14] A di-coordinating amine ligand was also appraised, namely ethylenediamine (EDA) as well as the tetracoordinating crown-ether (12-crown-4, 12C4).[1] Those correspond to additives encountered in many experimental procedures.
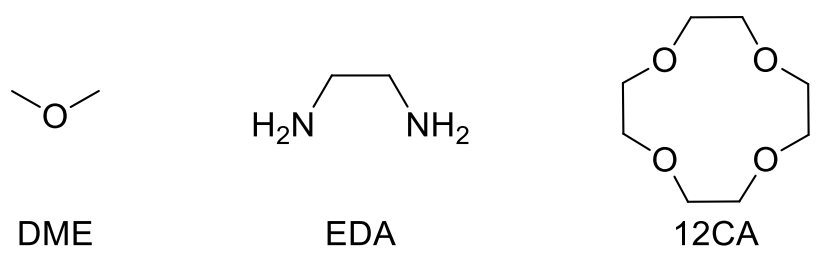

Figure 1: Schematic representation of the ligands examined: dimethylether (DME), ethylenediamine (EDA), 12-crown-4 $(12 \mathrm{C} 4)$

In a first part, we describe and justify our computational approach. We next examine the modulation of the coordination in two prototypical organolithium compounds, namely methyl and allyllithium. Finally, the possibility of extending this method to sample lithium coordination by polydentate organometallic anions is examined.

\section{Results and discussion}

“Weakening” of the Li center. In a first step, the neutral ligands described in Figure 1 are coordinated to $\mathrm{Li}^{+}$center, yielding cationic complexes. In such systems, a simple donor-acceptor orbital model (Figure 2) predicts a raise of the energy of the BV through coordination of a Lewis base to $\mathrm{Li}^{+}$, whereas effects on the filled ligand-centered orbital is expected to be minimal (non-bonding interaction) or stabilizing (bonding interactions).[15] 


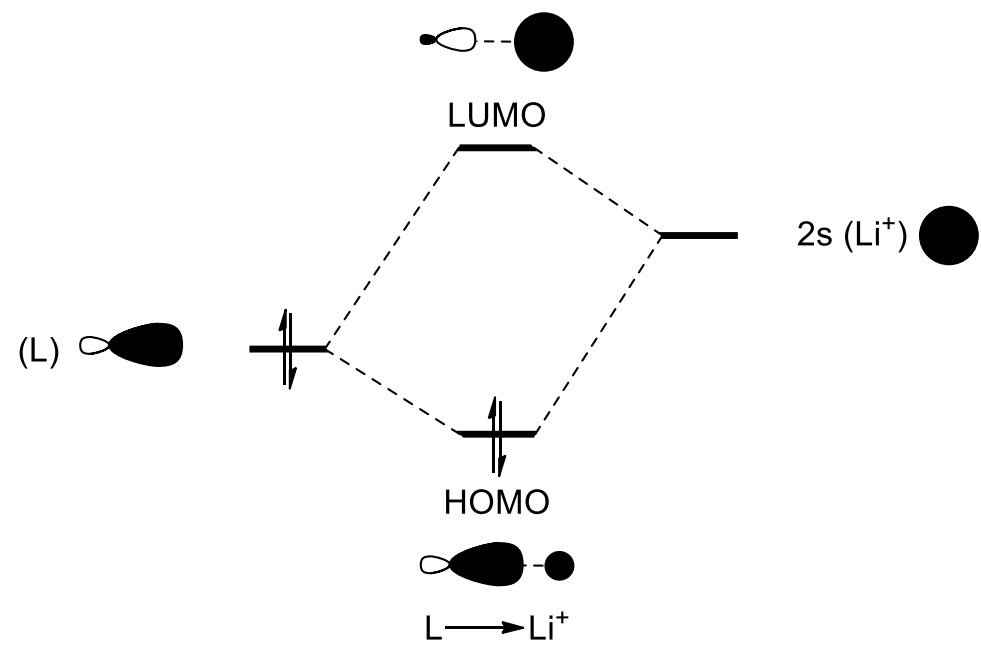

Figure 2: Schematic representation a ligand $-\mathrm{Li}^{+}$orbital interaction, evidencing the increase of the Lowest Unoccupied Molecular Orbital (LUMO) energy

Full geometry optimization of these complexes was carried out with the Gaussian 09 program[16] and within the framework of the Density Functional Theory (DFT), using the hybrid B3LYP exchangecorrelation functional[17-18] and the $6-31+\mathrm{G}^{* *}$ basis set for all atoms. The energy and expression of the canonic orbitals were examined and those essentially localized on the Li center are reported in Table 1. In line with the simple model in Figure 2, we observe a raise of the energy of the Li 2s (LUMO) and $2 p(L U M O+1)$ orbitals. In addition, and more surprisingly, an up-shift of the core Li 1s orbital is also observed, and is larger for these core electrons (up to 0.30 a.u.) than for the valence ones (up to 0.13 a.u. for the $2 \mathrm{~s}$ level and 0.067 a.u. for the $2 \mathrm{p}$ one). This shift increases with the number of coordinated $\mathrm{Me}_{2} \mathrm{O}$, and is similar for the di-coordinating EDA and for two $\mathrm{Me}_{2} \mathrm{O}$. The four-coordinated $12 \mathrm{C} 4$ leads results similar to three $\mathrm{Me}_{2} \mathrm{O}$, most probably as the coordination is planar in both systems.

The fact that all orbitals are destabilized, including core electrons, confirms the possibility to reproduce such an increase of the orbital energies through addition of a simple pseudopotential on the Li center. Considering the standard expression of the effective potential is given by equation 1 , a simple expression can be obtained taking $\alpha$ and $\mathrm{n}$ equal to 0 and n' to 1 , and limiting the summation to a single term (equation 2).[9] As such, variations are handled through a single variable coefficient $\mathrm{c}$. It will be referred below as $\mathrm{Li}^{*}$. A sample commented Gaussian Input for MeLi is given in S.I.. 


$$
\begin{gathered}
V(r)=-\frac{Z-n}{r}+\sum_{j} c_{j} r^{n^{\prime}-2} e^{-\alpha r^{2}} \\
V(r)=-\frac{Z}{r}+c r^{-1}
\end{gathered}
$$

A regular $\mathrm{Li}$ center is obtained for $\mathrm{c}=0$. Using a negative value for $\mathrm{c}$ is thus similar to increasing the nuclear charge. As illustrated in Table 1, this stabilizes all the orbitals. On the opposite, a positive c corresponds to a decrease of the nuclear charge and leads to a destabilization of the Li orbitals, similar to that obtained in the case of ligands coordination.

\begin{tabular}{|l|l|l|l|}
\hline & $\mathrm{E}(1 \mathrm{~s})$ & $\mathrm{E}(2 \mathrm{~s})(\mathrm{LUMO})^{\mathrm{a}}$ & $\mathrm{E}(2 \mathrm{p})(\mathrm{LUMO}+1)^{\mathrm{b}}$ \\
\hline $\mathrm{Li}^{+}$ & -64.0 & -6.9 & -4.6 \\
\hline$[\mathrm{Li}$ & -55.1 & -1.7 & -0.5 \\
\hline$\left[\mathrm{Li}\left(\mathrm{OMe}_{2}\right)^{+}\right.$ & -61.0 & -5.7 & -4.1 \\
\hline$\left.\left[\mathrm{Oi}\left(\mathrm{OMe}_{2}\right)_{2}\right)_{3}\right]^{+}$ & -58.5 & -4.4 & -3.4 \\
\hline$\left[\mathrm{Li}(\mathrm{OMe})_{4}\right]^{+}$ & -56.9 & -3.7 & -3.0 \\
\hline$\left[\mathrm{Li}(\mathrm{EDA})^{+}\right.$ & -55.9 & -3.3 & -2.8 \\
\hline$[\mathrm{Li}(\mathrm{Crown})]^{+}$ & -58.7 & -4.8 & -3.7 \\
\hline $\mathrm{Li}^{*}, \mathrm{c}=-0,100$ & -57.0 & -3.5 & -3.3 \\
\hline $\mathrm{Li}^{*}, \mathrm{c}=+0,100$ & -71.0 & -7.9 & -5.4 \\
\hline $\mathrm{Li}^{*}, \mathrm{c}=-0,100$ & -57.1 & -6.0 & -3.9 \\
\hline $\mathrm{Li}^{*}, \mathrm{c}=+0,100$ & -61.8 & -2.2 & -1.0 \\
\hline
\end{tabular}

Table 1: Energies (in eV) of the lithium cation orbitals as a function of the coordination of a neutral ligand or of the coefficient applied in the $\mathrm{Li}^{*}$ pseudopotential. Lithium atom values are given for complete information. a) For $\mathrm{Li}$ atom, SOMO. B) For Li atom, LUMO.

Following simple orbital models, this high energy shift of the LUMO energy upon increase of the c coefficient should afford less electrophilic $\mathrm{Li}^{*+}$ species and to weaker Lewis acidic properties. 
Therefore, coordination of solvent molecules or chelating additives on $\mathrm{Li}^{+}$reduces its Lewis acidity, an effect which can be reproduced by addition of a simple pseudopotential centered on the $\mathrm{Li}^{*}$ center.

To confirm this orbital description, the impact of the pseudopotential on the reactivity indices of $\mathrm{Li}^{*} \mathrm{CH}_{3}$ was examined. As a consequence, the $\mathrm{Li}^{*} \mathrm{CH}_{3}$ ionization potential (I) and electron affinity (A) were computed. Evaluation of I was carried out using the standard procedure $\left(\mathrm{I}=\mathrm{E}\left(\mathrm{Li}^{*} \mathrm{CH}_{3}{ }^{+}\right)-\mathrm{E}\left(\mathrm{Li}^{*} \mathrm{CH}\right)\right)$. In contrast, evaluation of the electron affinity thanks to the $\mathrm{Li}^{*} \mathrm{CH}_{3}$ anion $\left(\mathrm{A}=\mathrm{E}\left(\mathrm{Li}^{*} \mathrm{CH}_{3}\right)-\mathrm{E}\left(\mathrm{Li}^{*} \mathrm{CH}_{3}^{-}\right)\right)$ leads to negative values in some cases, a well-known problem associated to DFT methods (see S.I.). We thus used an alternative expression proposed in the literature $(\mathrm{A}=-(\mathrm{E}(\mathrm{HOMO})+\mathrm{E}(\mathrm{LUMO}))-\mathrm{I})$.[19] This value was used to compute the chemical potential $\mu$, the hardness $\eta$ and the electrophilicity $\omega$ using the model and approximations described in the literature: $\mu=-0.5 .(\mathrm{I}+\mathrm{A}) ; \eta=\mathrm{I}-\mathrm{A}$ and $\omega=\mu^{2} /(2 \eta)$ (Figure 3).[20-21] An increase of the chemical potential while c increases is obtained, whereas hardness and electrophilicity decrease. It confirms the results obtained on $\mathrm{Li}^{*+}$ : the higher the pseudopotential coefficient $\mathrm{c}$, the weaker the electrophilic properties of the lithiated species, in line with weaker Lewis acidity of $\mathrm{Li}^{+}$.

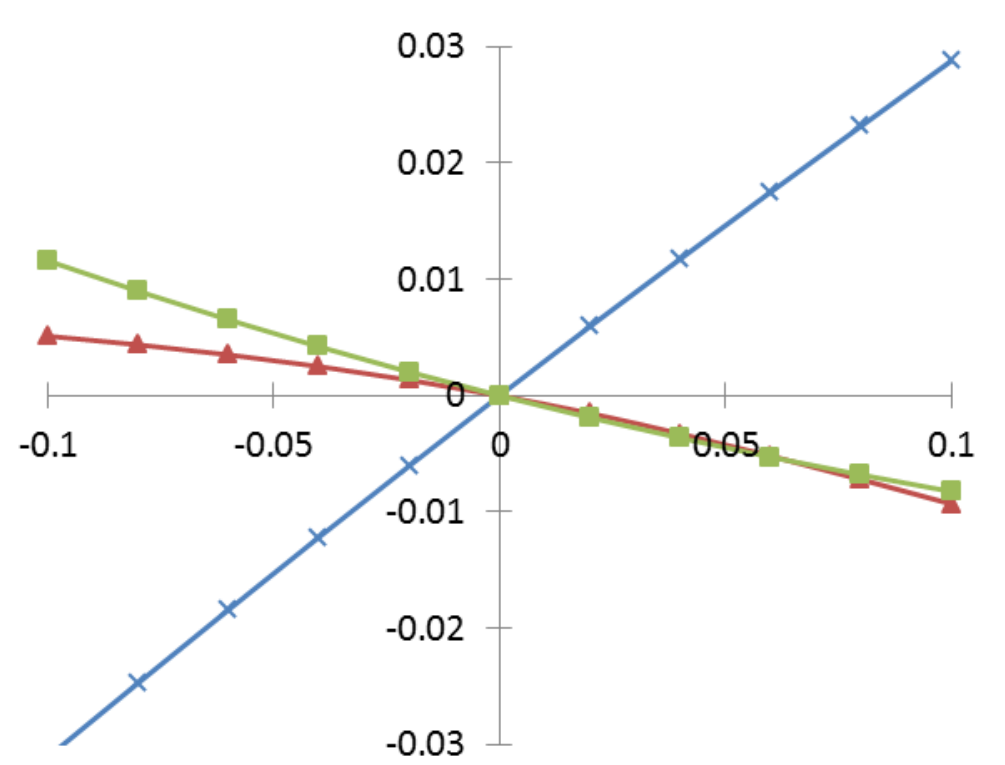

Figure 3: Variation (in atomic units) of the chemical potential $\mu$ (crosses, blue), chemical hardness $\eta$ (triangles, red) and electrophilicity $\omega$ (squares, green) in $\mathrm{Li}^{*} \mathrm{CH}_{3}$ with respect to $\mathrm{LiCH}_{3}$ as a function of c 
These results indicate that the $\mathrm{Li}^{*}$ model allows effective tuning of the electrophilicity of Li-systems.

Influence on the structure of organolithium species. We then examined how electrophilicity impacts structure and coordination properties in organolithium compounds. Two prototypic examples were considered to investigate this point: the simplest methyllithium and the conjugated allyllithium.

One of the well-known effects associated to ligand coordination to methyllithium is a significant lengthening of the $\mathrm{Li}-\mathrm{C}$ distance. When binding from one to three $\mathrm{Me}_{2} \mathrm{O}$ molecules to $\mathrm{Li}$ in $\mathrm{Li}-\mathrm{CH}_{3}$, the Li-C bond rises from $1.985 \AA$ in absence of coordination to $1.998,2.034$ and $2.085 \AA$, respectively. [22] A similar lengthening is obtained with one molecule of EDA (2.030 $)$ ). In order to determine whether the decreased electrophilicity of $\mathrm{Li}$ is at the origin of this significant elongation, the $\mathrm{Li}^{*}-\mathrm{CH}_{3}$ geometry was optimized for $\mathrm{c}$ values ranging from -0.1 to +0.1 . A monotonous increase (Figure 4 ) of the $\mathrm{Li}^{*}-\mathrm{C}$ bond with $\mathrm{c}$ is observed and results in a full decoordination of the lithium from the $\mathrm{CH}_{3}{ }^{-}$moiety for $\mathrm{c}=$ 0.100. As a consequence, the decrease of the electrophilicity triggered by the ligand coordination fully accounts for the lengthening of the $\mathrm{Li}-\mathrm{C}$ distance in $\mathrm{Li}-\mathrm{CH}_{3}$, and there is no need to invoke $\mathrm{CH}_{3}$-ligand steric effects. In conclusion, the $2.085 \AA \mathrm{Li}-\mathrm{CH}_{3}$ distance computed for $\left(\mathrm{Me}_{2} \mathrm{O}\right)_{3}-\mathrm{LiCH}_{3}$ is close to that obtained for $\mathrm{c}=+0.020$, which suggests that values of $\mathrm{c}$ in the $0-0.020$ range are relevant for studies of ligand effects on coordination properties of organolithium compounds. 


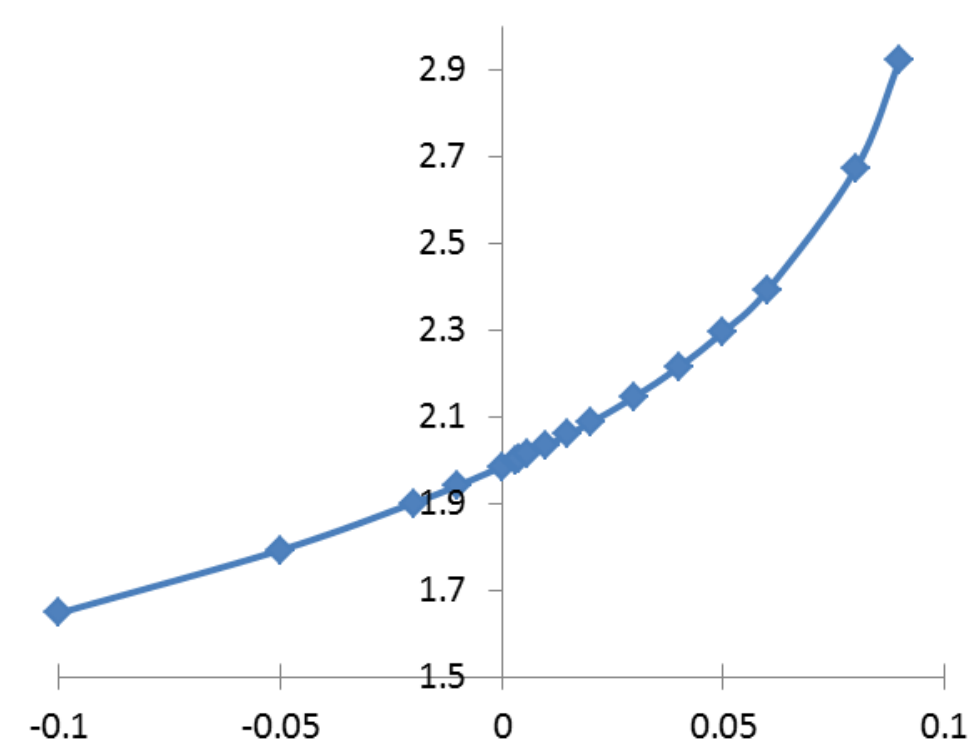

Figure 4: Length of the $\mathrm{Li}^{*}-\mathrm{C}$ bond in $\mathrm{CH}_{3} \mathrm{Li}$ (in $\AA$ ) as a function of the pseudopotential coefficient c

In a next step, we examined the effect of the fictitious charge on the interaction between $\mathrm{Li}^{*+}$ and the organic chain in allylithium (see Figure 5), a canonical model for delocalized carbanions.[8] The partition between the various coordination mode of $\mathrm{Li}^{+}$in this system, described in Figure 5, has been a long time concern and it is supposed to depend on the solvent and other additives present in the reaction medium.[23]

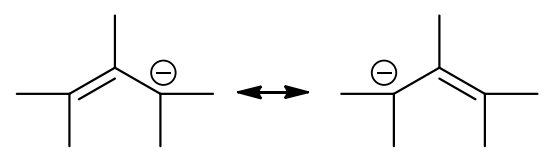

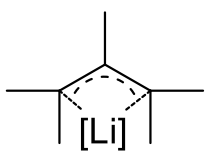

Bridged

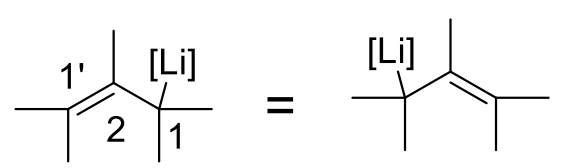

Terminal

Figure 5: Allyl anions, naked (left) and in interaction with a lithium cation in a bridged (center) or terminal (right) mode.

When the lithium is "naked" (no solvation), a bridged structure is obtained, in agreement with experimental observations in non-coordinating solvents. A similar structure is obtained when one or two $\mathrm{OMe}_{2}$ molecules are coordinated to the Li center. In contrast, when a third molecule is added, a structure exhibiting terminal bonding can also be characterized, which is found to be quasi-isoenergetic to the bridged one (more stable by $0.4 \mathrm{kcal} \mathrm{mol}^{-1}$ ). A better insight on this change of behavior upon solvation 
is obtained through a relaxed scan of the $\mathrm{C}^{2}-\mathrm{C}^{1}-\mathrm{Li}$ angle (Figure 6), starting from the bridged structure (angle close to $68^{\circ}$ ) and increasing it up to terminal bonding (about $118^{\circ}$ ). Addition of $\mathrm{Me}_{2} \mathrm{O}$ molecules decreases the preference for the bridged structure, the surface becomes flat and a small potential energy well appears in the trisolvated structure. Repeating a similar angular scan this time in the absence of $\mathrm{Me}_{2} \mathrm{O}$ but for $\mathrm{c}$ ranging from 0 to 0.04 leads to a behavior highly similar to that observed upon consecutive addition of solvent molecules. With increasing values of $c$, the potential energy surface becomes flatter and, for the highest values, a second minimum corresponding to a localized structure is observed, which gradually becomes more stable than the bridged one. Through full geometry optimization, it was possible to determine that the bridged structure is obtained for all values of $\mathrm{c}$, whereas the localized one can be optimized only if $c>0.015$. The localized structure even becomes the most stable one for $\mathrm{c}=0.020$, the energy barrier between the two local minima being $<2.5 \mathrm{kcal} \mathrm{mol}^{-1}$. For $\mathrm{c}=0.040$, the terminal bonding becomes $13.2 \mathrm{kcal} \mathrm{mol}^{-1}$ more stable (potential energy, without correction) than the bridged one. A closer look at the terminally bonded structures reveals a dissymmetry in the $\mathrm{C}-\mathrm{C}$ distance, the Li-bonded $\mathrm{C}=\mathrm{C}$ being $0.12 \AA$ longer than the other one, whatever the value of $\mathrm{c}$. Let us highlight that the energy curve for the monosolvated structure highly ressembles that for $\mathrm{c}=0.004$, whereas disolvation leads to a result close to $\mathrm{c}=0.008$ and trisolvation to $\mathrm{c}=0.020$ (Figure 6, left). Once again, the decrease of the electrophilicity associated to solvent coordination is sufficient to account for the terminal binding of Li to the allyl anion, and there is no need for an extra steric hindrance between solvent and the allenyl moiety to justify this behavior. 

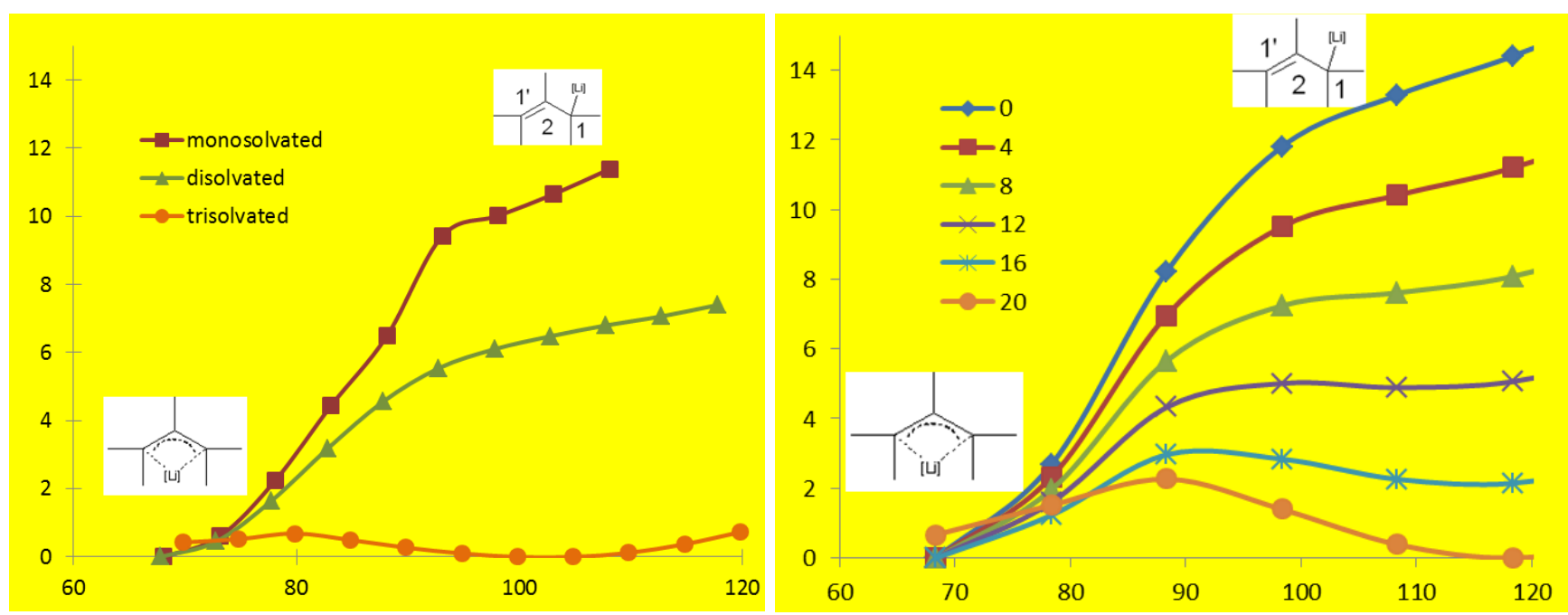

Figure 6 : Potential rnergy of the most stable structure (in $\mathrm{kcal} \mathrm{mol}^{-1}$, computed with respect to the most stable point) as a function of the $\mathrm{C}^{2}-\mathrm{C}^{1}$ - $\mathrm{Li}$ angle (between 68 and $118^{\circ}$ ) for various solvation levels (level) or values of $\mathrm{c}$ (right)

A deeper insight on the electronic effects at stake in this structural change can be obtained by an analysis of the electron localization function[24] (ELF, Figure 7) with the TopMod18 suite of programs.[26] It allows the partition of the electronic density in terms of lone pairs (monosynaptic ELF basins, red) and bonds (disynaptic basins, green).[27] The delocalized anion is characterized by 2.06 electrons forming four monosynaptic basins located on each side of the allenyl plane on both 1 and 1 ' carbon atoms, interpreted as a $\pi$-delocalized lone paire. When a $\mathrm{Li}^{+}$cation comes to bridge this structure, the electron pair $(2.10 \mathrm{e})$ rearranges on the side of the allenyl anion coordinating the $\mathrm{Li}^{+}$. Two symmetrical monosynaptic basins arise in this complex. This corresponds to a lone pair delocalized on 1 and 1 ' carbon atoms, in electrostatic interaction with the $\mathrm{Li}^{+}$cation. This structure is similar whatever the value of the c coefficient on the $\mathrm{Li}^{*}$ center. In the case of a terminal interaction, a more drastic rearrangement takes place and a disynaptic Li-C basin emerges, strongly polarized toward C (92\%). This is associated to a polarization of the electron density on the Li bonded side (total population on the Li bonded side equal to $3.90 \mathrm{e}$ compared to $3.53 \mathrm{e}$ on the other one). In addition, natural population analysis shows a significantly stronger donation toward $\mathrm{Li}$ in the terminal structure compared to the bridged one (for $\mathrm{c}=0.02,0.18$ versus $0.03 \mathrm{e}$ population of the $2 \mathrm{~s} \mathrm{Li}$ orbital are found respectively). As a conclusion, in the case of delocalized organolithium species, adding bonding ligands or decreasing the 
hardness of $\mathrm{Li}^{*}$ leads to chemical structures exhibiting important electronic rearrangements, associated to more localized, and thus more covalent, bonding between Li and the organic chain.

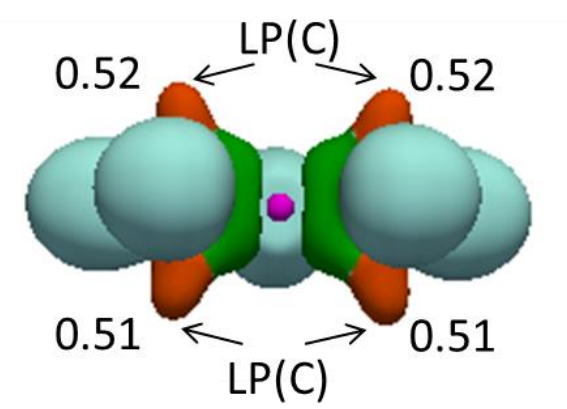

Anion



Bridging

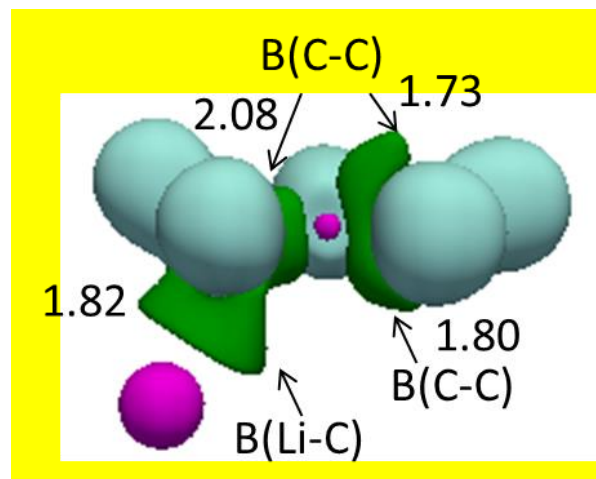

Terminal

Figure 7: Electronic description (0.75 ELF isodensity colored in green is for bonds (B), red for lone pairs (LP), pink for core electrons and blue for $\mathrm{CH}$ bonds, carried out using the Paraview program[25]) of the allyl anion (left) and of $\mathrm{Li}^{*}(\mathrm{c}=0.02)$ coordinated structures in a bridged (center) or terminal (right) fashion. Population for the labelled basins is given (in electron).

\section{Application to the structural studies of lithiated organometallics: Formation of bridged structures} when using a "naked" $\mathrm{Li}^{+}$in lithiated organometallics is a well known phenomenon, and those are sometimes proposed to play a major role in the reactivity.[28] Nevertheless, these structures do not reflect the real structure of these compounds which are generally used in coordinating ethereal solvents. Two examples encountered in our groups are gathered in Figure 8, evidencing the generality of the problem.

We have previously reported on lithium phosphidoborane $\left[\mathrm{PH}_{2} \mathrm{BH}_{3}\right] \mathrm{Li}$, a compound for which both $\mathrm{P}$ nucleophilicity and hydridic reduction reactivity are observed.[3] The lithium cation can interact either with the phosphorus or with the hydrides borne by the boron, and we proposed that this ditopicity is directly related to its ambiguous reactivity. We focus below on the Li-P interaction. The second system is a lithiated allenyl-cyanocuprate. An intermediate $\mathrm{Li} \ldots \mathrm{C}=\mathrm{C}$ interaction is expected in the course of its reactivity with aldehyde and the proper description of such structures is crucial. 
(1)<smiles>[CH]P[PH3]</smiles>

(2)

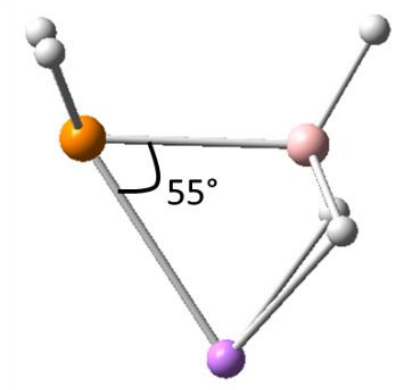

(3)

(4)

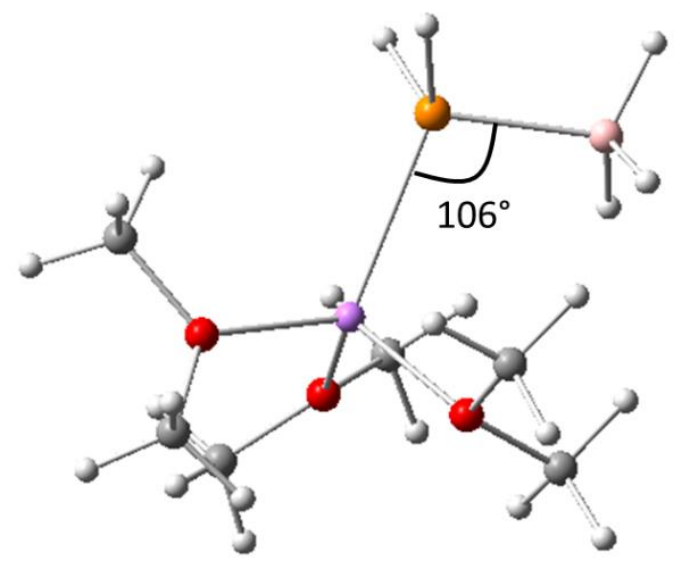

(a)<smiles>C[C@H]([AlH2])/C([SiH3])=C(/[SiH3])[CH]C#N</smiles>
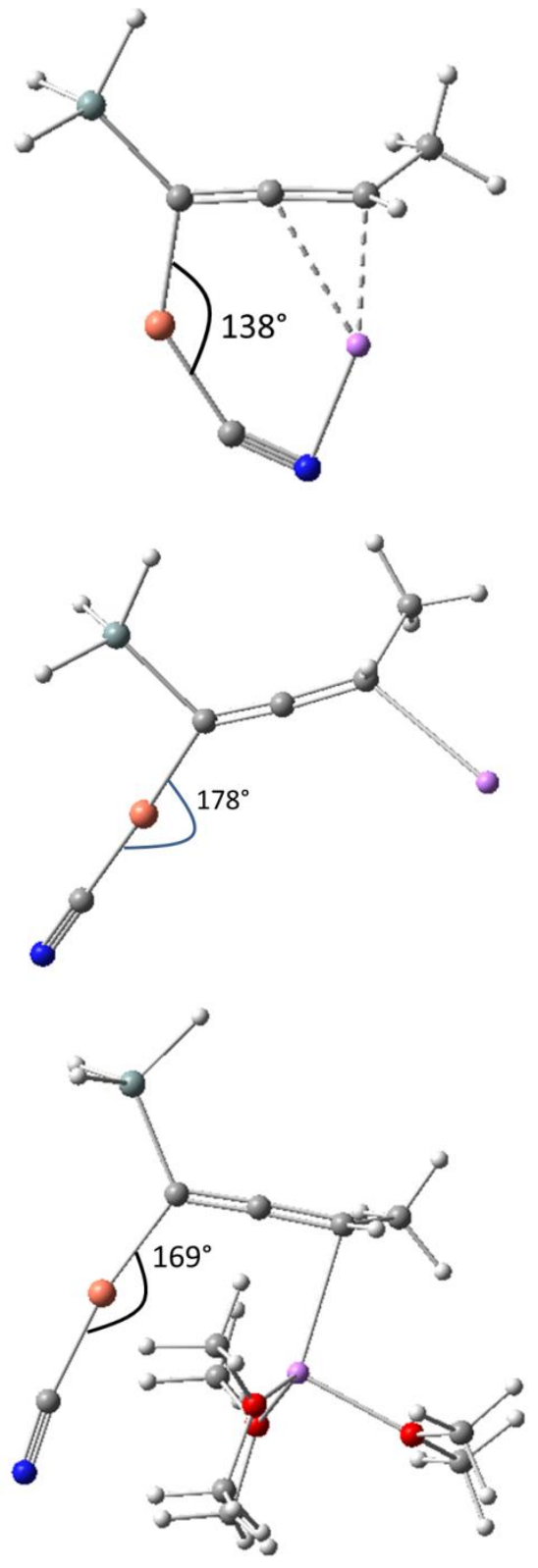

(b)

Figure 8: Versatility of the Li binding mode as a function of the modelling method, illustrated for Lithium phosphide-borane (a) and lithiated allenylcyanocuprate (b). Entries correspond to structures (1): expected; (2): obtained with $\mathrm{c}=0$; (3): obtained with $\mathrm{c}=0.02 \mathrm{Li}^{*}$; (4): explicitly solvated by $3 \mathrm{OMe}_{2}$ molecules. 
Searching for a sole Li-P interaction in lithium phosphidoborane leads, if $\mathrm{c}=0$, to a structure exhibiting two additional coordinations, between the Li and two of the hydrides (Figure 8a2). This structure is analogous to the bridged structure encountered for allyllithium. In contrast, when the lithium center is explicitly solvated by adjunction of three $\mathrm{OMe}_{2}$ molecules, a terminal P-bonded form can be obtained (Figure 8a4). Such a trisolvated structure is much more representative of the experimental system, as the reaction always takes place in ethereal solvent, or in the presence of a significant amount of ethereal molecules. A comparable solely P-bonded arrangement is also obtained using a $\mathrm{Li}^{*}$ with c values equal to or larger than $0.018(\mathrm{c}=0.02$ given in Figure 8a3).

A similar behavior is obtained for lithiated allenylcyanocuprate.[4] The non-solvated structure exhibits a strongly distorted coordination at $\mathrm{Cu}\left(\mathrm{C}-\mathrm{Cu}-\mathrm{C}=138^{\circ}\right.$ instead of the expected $\left.180^{\circ}\right)$ which allows the formation of an additional Li-NC interaction. Decreasing the electrophilicity of the Li center through addition of explicit $\mathrm{OMe}_{2}$ molecules or inclusion of a pseudopotential according to the $\mathrm{Li}^{*}$ model decreases this distorsion $\left(169^{\circ}\right.$ and $178^{\circ}$ resp. $)$ and leads to a more localized $\mathrm{Li}-\mathrm{C}=\mathrm{C}$ interaction.

These two examples highlight that using $\mathrm{Li}^{*}$, a structure alike that of an "explicitly solvated Li" can be obtained for the cost of "naked Li" calculation.

\section{Conclusion}

In this study, we describe a computational experiment, referred to as $\mathrm{Li}^{*}$, consisting in tuning the $\mathrm{Li}$ chemical potential. Our test is run in the context of structure optimizations in order to determine how electrophilicity of the lithium influences its binding properties. The results illustrate that decreasing the chemical potential of this cation has a major impact on the $\mathrm{Li}^{*}-\mathrm{C}$ bond and on the geometry of its coordination to delocalized anions. In these cases, the $\mathrm{Li}^{*}$ model mimics efficiently an explicit solvation. From a computational point of view, the procedure is extremely simple, computationally economical and reproduces the variation of structure as a function of electrophility modification upon solvent coordination. This model, which can be contiuously varied, in strong contrast to the number of solvent molecules,[29] could be used to mimic the variety of electronic effects associated to the 
chelating additives used in lithium organometallic chemistry and help to reproduce their structure and reactivity. This is why we believe that it can become an efficient tool to help experimentalists to select the best reaction conditions to achieve a given selectivity. Currently, this topic is hardly addressed by theoreticians due to the complexity (both in size and structure) of the resulting reagent-ligand complexes. In addition, by its ability to quantify, by difference, the plasticity of the solvent sphere along the reaction course, it can be regarded as a probe to analyse the solvent effects in systems where solvent rearrangements play a major role.

Acknowledgments: The authors thank the ANR (AGGREGATE project: ANR-07-BLAN-0294) for financial support. H.G. thanks Marie-Liesse DOUBLET for insighfull discussions and Emmanuel VRANCKEN for continuous support to this project.

\section{Bibliography:}

[1] Reich HJ (2013) Role of Organolithium Aggregates and Mixed Aggregates in Organolithium Mechanisms. Chem. Rev. 113:7130-7178

[2] Essafi S, Tomassi S, Aggarwal VK, Harvey JN (2014) Homologation of Boronic Esters with Organolithium Compounds: A Computational Assessment of Mechanism. J. Org. Chem. 79:12148-12158

[3] Barozzino Consiglio G, Queval P, Harrison-Marchand A, Mordini A, Lohier J-F, Delacroix O, Gaumont AC, Gérard H, Maddaluno J, Oulyadi H (2011) Ph2P(BH3)Li: from ditopicity to dual reactivity. J. Am. Chem. Soc. 133: 6472-6480

[4] Vrancken E, Gérard H, Linder D, Ouizem S, Alouane N, Roubineau E, Bentayeb K, Marrot J, Mangeney P (2011) Diastereodivergent Behavior of Alkyl- versus Cyano- Allenylcuprates towards Aldehydes: a Key Role for Lithium. J. Am. Chem. Soc. 133: 10790-10802

[5] Jacques B, Chanaewa A, Chavarot-Kerlidou M, Rose-Munch F, Rose E, Gérard H (2008) A combined experimental - theoretical study on the lithiation/electrophilic quench sequence of $\left(\eta^{5}\right.$ cyclohexadienyl) $\mathrm{Mn}(\mathrm{CO})_{3}$ complexes. Organometallics 27:626-636

[6] Lisson Lill SO (2014) Computational perspectives in Organolithiums. In: Luisi R, Capriati V (ed) Lithium Compounds in Organic Synthesis. Wiley-VCH, Weihneim, p 48-72.

[7] Kost D, Klein J, Streitwieser A, Schriver GW (1982) Ab initio calculations of dilithiopropenes. Proc. Natl. Acad. Sci. U. S. A. 79:3922-3926 
[8] Clark T, Rohde C, von Ragué Schleyer P (1983) Allyllithium, Allylsodium, and Allylmagnesium Hydride: Geometries and Bonding. A Comparative ab Initio Study. Organometallics 2:13441351

[9] Dumont E, Chaquin P (2004) The Hp method: hydrogen atoms with a fictitious nuclear charge. A versatile theoretical tool for study of atom and group properties as substituents: electronegativity and partition of $\sigma$ and $\pi$ contributions. J. Mol. Struct. THEOCHEM 680:99-106

[10] Dumont E, Chaquin P (2006) Diels-Alder reaction: A theoretical comprehensive study of substituent effects using the 'H* method'. J. Mol. Struct. THEOCHEM $758: 161-167$

[11] Dumont E, Chaquin P (2007) Investigation of pure inductive effects on benzene ring by ${ }^{13} \mathrm{C}$ NMR chemical shifts: A theoretical study using fictitious nuclear charges of hydrogen atoms (' $\mathrm{H}^{*}$ method'). Chem. Phys. Lett. 435:354-357

[12] Dumont E, Chaquin P (2009) Inductive Effects on Proton Affinity of Benzene Derivatives: Analysis Using Fictitious Hydrogen Atoms. J. Phys. Chem. A 113:2990-2994

[13] De La Lande A, Gérard H, Parisel O (2008) How to optimize a C-H cleavage with a mononuclear copper-dioxygen adduct? Int. J. Quantum Chem. 108:1898-1904

[14] Pratt L (2007) Modeling lithium dialkylamides in ethereal solvents: A test of the microsolvation model. J. Mol. Struct. THEOCHEM 811:191-196

[15] Miessler GL, Tarr DA (1991) Inorganic Chemistry. Prentice-Hall, Englewood Cliffs

[16] Frisch MJ et al. (2009) Gaussian 09, Revision D.01

[17] Becke A (1993) Density-functional thermochemistry. III. The role of exact exchange J. Chem. Phys. 98:5648-5652

[18] Lee C, Yang W, Parr RG (1988) Development of the Colle-Salvetti correlation-energy formula into a functional of the electron density. Phys. Rev. B 37:785-789

[19] Tozer DJ, De Proft F (2005) Computation of the Hardness and the Problem of Negative Electron Affinities in Density Functional Theory. J. Phys. Chem. A 109:8923-8929

[20] Parr RG, Szentpály LV, Liu S (1999) Electrophilicity Index. J. Am. Chem. Soc. 121:1922-1924

[21] Chattaraj PK, Giri S, Duley S (2011) Update 2 of: Electrophilicity Index. Chem. Rev. 111:PR43PR75

[22] Parisel O, Fressigné C, Maddaluno J, Giessner-Prettre C (2003) Influence of the Correlation, Aggregation, and Solvation on ab initio Computed $\mathrm{Li}-\mathrm{C}, \mathrm{Li}-\mathrm{N}$, and $\mathrm{Li}-\mathrm{Li}$ NMR Coupling Constants. J. Org. Chem. 68:1290-1294

[23] Fraenkel G, Chow A, Winchester WR (1990) Stereochemistry of Solvation of Benzylic Lithium Compounds: Structure and Dynamic Behavior. J. Am. Chem. Soc. 112:2582-2585

[24] Fourré I, Gérard H, Silvi B (2007) How the topological analysis of the electron localization function accounts for the inductive effect. J. Mol. Struc.: THEOCHEM 811:69-76 
[25] Ahrens J, Geveci B, Law C (2005) ParaView: An End-User Tool for Large Data Visualization. In: Hansen CD, Johnson CR Ed. Visualization Handbook, Elsevier. (b) Ayachit U (2015) The ParaView Guide: A Parallel Visualization Application Kitware

[26] Noury S, Krokidis X, Fuster F, Silvi B (1999) Computational tools for the electron localization function topological analysis. Comput. Chem. 23:597-604

[27] Piquemal JP, Pilmé J, Parisel O, Gérard H, Fourré I, Bergès J, Gourlaouen C, de la Lande A, van Severen M-C, Silvi B (2008) What can be learnt on biological-relevant systems from the topological analysis of the Electron Localization Function ? Int. J. Quant. Chem. 108:1951-1969

[28] Mori S, Hirai A, Nakamura M, Nakamura E (2000) Correlation of Reactivities of Organocuprate(I) and Zincate(II) with d-Orbital Energies of Ate Complexes. Tetrahedron 56:2805-2809

[29] Tomasevitch LL, Collum DB (2013) Structure Determination Using the Method of Continuous Variation: Lithium Phenolates Solvated by Protic and Dipolar Aprotic Ligands. J. Org. Chem. 78:7498-7507 


\section{Suplementary Information to :}

\section{Ligand effects on coordination properties of organolithium compounds: insights from computational experiments on a "weakened" $\mathrm{Li}^{+}$}

Hélène GERARD ${ }^{1}$, Patrick CHAQUIN ${ }^{1}$ and Jacques MADDALUNO ${ }^{2}$

1: Sorbonne Université, CNRS, Laboratoire de Chimie Théorique, LCT, F-75005 Paris, France. helene.gerard@sorbonne-universite.fr ; Tel : (+33) 144279662

2 : Normandie Univ, UNIROUEN, INSA Rouen, CNRS, COBRA, (UMR 6014 \& FR 3038), F-76000, Rouen, France

Summary: A simple numerical experiment is presented, which allows tunig the lithium electrophilicity, in a manner similar to solvent and additives coordination. Coordination of $\mathrm{Li}^{+}$to carbanions or polydentate nucleophiles is examined, highlighting the potential of this chemical trick to both model and decipher the effects of solvation of the structural properties lithiated organometallics.

Keywords : Lithium; Carbanions ; An initio calculations ; Molecular Modeling ; Solvent effects

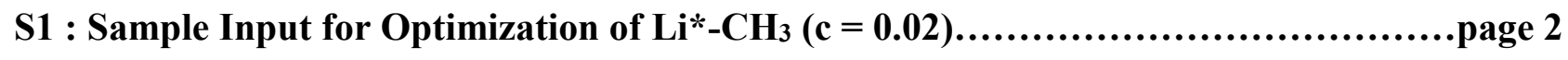

S2 : Data for systems as a function of c ...................................................page 3

S3 : Optimized geometries (regular Li) …...................................................page 4

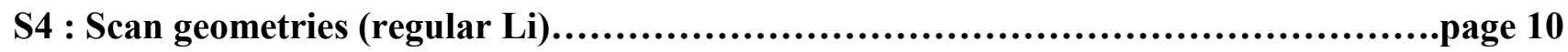




\section{S1 : Sample Input for Optimization of $\mathrm{Li}^{*}-\mathrm{CH}_{3}(\mathrm{c}=0.02)$}

\#P B3LYP gen 6D nosym pseudo=read g
opt=(CalcFC,Maxcycl=200)
MeLi
$\begin{array}{cccc}01 & & & \\ 6 & .395730 & .000155 & -.000035 \\ 3 & -1.603499 & .000321 & -.000062 \\ 1 & .813838 & 1.004693 & -.208173 \\ 1 & .811156 & -.322887 & .974880 \\ 1 & .811127 & -.683700 & -.766309\end{array}$

\section{Li H C 0 \\ 6-31+G** \\ $* * * * * * * * *$}

$\begin{array}{ll}\text { Li } 0 & \% \text { introduction line for the pseudo } \\ \text { Star } 00 & \% \text { Pseudo name - applied to s and higher - replaces } 0 \text { e } \\ \text { S component } & \% \text { Description } \\ 1 & \% \text { Only one term in the pseudo } \\ 10.00 .020 & \% 1 \text { term - exp coefficient - c value }\end{array}$


S2 : Data for systems as a function of c

\begin{tabular}{|l|l|l|l|l|l|}
\hline $\mathrm{c}$ & $\mathrm{MeLi}+$ & $\mathrm{MeLi}$ & $\mathrm{MeLi}-$ & $\mathrm{I}$ & $\mathrm{A}$ \\
\hline-0.100 & -47.89881 & -48.2089862 & -48.2429009 & 0.31017617 & 0.03391468 \\
\hline-0.080 & -47.7453798 & -48.0488158 & -48.0786515 & 0.30343595 & 0.02983577 \\
\hline-0.060 & -47.5921175 & -47.8888199 & -47.9147147 & 0.29670239 & 0.02589481 \\
\hline-0.040 & -47.4390296 & -47.7290053 & -47.7510981 & 0.2899757 & 0.02209282 \\
\hline-0.020 & -47.286123 & -47.5693791 & -47.5878092 & 0.2832561 & 0.01843012 \\
\hline 0.0 & -47.1334051 & -47.409949 & -47.4248554 & 0.27654391 & 0.01490633 \\
\hline 0.020 & -46.9808837 & -47.2507232 & -47.2622437 & 0.26983944 & 0.01152048 \\
\hline 0.040 & -46.8285671 & -47.0917102 & -47.0810749 & 0.26314312 & -0.01063533 \\
\hline 0.060 & -46.6764639 & -46.9329194 & -46.9205529 & 0.25645541 & -0.0123665 \\
\hline 0.080 & -46.5245837 & -46.7743604 & -46.7602851 & 0.24977678 & -0.01407536 \\
\hline 0.100 & -46.3729361 & -46.6160441 & -46.6002806 & 0.24310798 & -0.01576349 \\
\hline
\end{tabular}

Table S2-1: ionization and electron affinity of MeLi computed using anionic and cationic species.

\begin{tabular}{|l|l|l|}
\hline $\mathrm{c}$ & $\mathrm{E}(\mathrm{u} . \mathrm{a})$. & $\mathrm{Li}-\mathrm{C}(\mathrm{A})$ \\
\hline-0.100 & -48.2344012166 & 1.648 \\
\hline-0.050 & -47.8152585131 & 1.793 \\
\hline-0.020 & -47.5704067999 & 1.901 \\
\hline-0.010 & -47.4898960616 & 1.941 \\
\hline 0.0 & -47.4099490372 & 1.985 \\
\hline 0.003 & -47.3860768937 & 1.999 \\
\hline 0.004 & -47.3781311591 & 2.004 \\
\hline 0.006 & -47.3622572774 & 2.013 \\
\hline 0.010 & -47.3305806821 & 2.033 \\
\hline 0.015 & -47.2911203890 & 2.059 \\
\hline 0.020 & -47.2518142117 & 2.086 \\
\hline 0.030 & -47.1736823133 & 2.146 \\
\hline 0.040 & -47.0962293811 & 2.214 \\
\hline 0.050 & -47.0195164007 & 2.295 \\
\hline 0.060 & -46.9436187364 & 2.391 \\
\hline 0.080 & -46.7947235841 & 2.671 \\
\hline 0.090 & -46.7221353948 & 2.922 \\
\hline
\end{tabular}

Table S2-2: optimization of MeLi* as a function of c 


$$
\begin{aligned}
& {\left[\mathrm{Li}\left(\mathrm{OMe}_{2}\right)\right]^{+}} \\
& 10
\end{aligned}
$$

scf done: -162.389192

$\begin{array}{rrrr}\mathrm{Li} & -1.129575 & -0.004389 & 0.000601 \\ \mathrm{O} & 0.679938 & -0.000949 & 0.000381 \\ \mathrm{C} & 1.485910 & 1.205828 & 0.000332 \\ \mathrm{C} & 1.490543 & -1.204619 & 0.000179 \\ \mathrm{H} & 2.109231 & 1.232156 & -0.897720 \\ \mathrm{H} & 0.804971 & 2.059444 & 0.000508 \\ \mathrm{H} & 2.109531 & 1.232026 & 0.898179 \\ \mathrm{H} & 2.113970 & -1.228426 & -0.897869 \\ \mathrm{H} & 2.114251 & -1.228536 & 0.898028 \\ \mathrm{H} & 0.812886 & -2.060843 & 0.000233\end{array}$

$\left[\mathrm{Li}\left(\mathrm{OMe}_{2}\right)_{2}\right]^{+}$

19

scf done: -317.484064

$\begin{array}{rrrr}\mathrm{Li} & -0.010937 & -0.499950 & -0.012467 \\ \mathrm{O} & -1.840114 & -0.679851 & -0.010496 \\ \mathrm{C} & -2.758426 & 0.436359 & 0.001944 \\ \mathrm{C} & -2.522384 & -1.954146 & -0.020672 \\ \mathrm{H} & -3.382205 & 0.395796 & 0.900136 \\ \mathrm{H} & -2.165002 & 1.352705 & 0.009084 \\ \mathrm{H} & -3.386314 & 0.412305 & -0.893970 \\ \mathrm{H} & -3.139838 & -2.053595 & 0.877306 \\ \mathrm{H} & -3.144893 & -2.036540 & -0.916870 \\ \mathrm{H} & -1.761275 & -2.736805 & -0.030276 \\ \mathrm{O} & 1.817775 & -0.314465 & -0.001806 \\ \mathrm{C} & 2.620507 & -0.183591 & -1.196727 \\ \mathrm{C} & 2.614201 & -0.277412 & 1.203893 \\ \mathrm{H} & 3.337546 & -1.008090 & -1.256109 \\ \mathrm{H} & 1.945819 & -0.222516 & -2.054161 \\ \mathrm{H} & 3.148533 & 0.774845 & -1.187986 \\ \mathrm{H} & 3.332121 & -1.103265 & 1.201631 \\ \mathrm{H} & 3.140786 & 0.679329 & 1.273618 \\ \mathrm{H} & 1.935176 & -0.384660 & 2.052027\end{array}$

$\left[\mathrm{Li}\left(\mathrm{OMe}_{2}\right)_{3}\right]^{+}$

28

scf done: -472.561406

$\begin{array}{cccc}\mathrm{Li} & -0.029360 & -0.062519 & -0.303729 \\ \mathrm{O} & -1.312482 & -1.438662 & -0.506018 \\ \mathrm{C} & -1.275649 & -2.686342 & 0.209939 \\ \mathrm{C} & -2.428410 & -1.355538 & -1.410856 \\ \mathrm{H} & -1.186629 & -3.523545 & -0.490959 \\ \mathrm{H} & -0.403499 & -2.662420 & 0.865428 \\ \mathrm{H} & -2.183503 & -2.804010 & 0.811476 \\ \mathrm{H} & -2.365379 & -2.149198 & -2.163202\end{array}$

$\begin{array}{rrrr}\mathrm{H} & -3.370905 & -1.444029 & -0.859562 \\ \mathrm{H} & -2.380471 & -0.381793 & -1.901139 \\ \mathrm{O} & -0.603029 & 1.737010 & -0.173453 \\ \mathrm{C} & -1.765256 & 2.148839 & 0.568315 \\ \mathrm{C} & 0.064599 & 2.841909 & -0.808964 \\ \mathrm{H} & -2.491266 & 2.626423 & -0.098728 \\ \mathrm{H} & -2.205850 & 1.253202 & 1.009314 \\ \mathrm{H} & -1.479292 & 2.846960 & 1.362494 \\ \mathrm{H} & -0.608661 & 3.331748 & -1.520785 \\ \mathrm{H} & 0.397261 & 3.566471 & -0.057667 \\ \mathrm{H} & 0.928997 & 2.440020 & -1.340032 \\ \mathrm{O} & 1.815613 & -0.474326 & -0.255567 \\ \mathrm{C} & 2.761833 & 0.166703 & 0.618698 \\ \mathrm{C} & 2.426627 & -1.477801 & -1.086635 \\ \mathrm{H} & 3.546430 & 0.657748 & 0.032746 \\ \mathrm{H} & 2.216955 & 0.911898 & 1.200531 \\ \mathrm{H} & 3.212017 & -0.569121 & 1.293874 \\ \mathrm{H} & 3.193768 & -1.024675 & -1.723769 \\ \mathrm{H} & 2.876819 & -2.260757 & -0.466623 \\ \mathrm{H} & 1.641485 & -1.909308 & -1.709661\end{array}$

$\left.\mathrm{Li}\left(\mathrm{OMe}_{2}\right)_{4}\right]^{+}$

37

scf done: -627.624483

$\begin{array}{rrrr}\mathrm{Li} & -0.662742 & 1.326759 & 4.988400 \\ \mathrm{O} & -0.321955 & -0.173210 & 6.223249 \\ \mathrm{O} & -2.092525 & 0.922135 & 3.694176 \\ \mathrm{O} & 1.066074 & 1.639220 & 4.093020 \\ \mathrm{C} & 2.324796 & 1.653068 & 4.779174 \\ \mathrm{C} & 1.206718 & 1.899572 & 2.689844 \\ \mathrm{C} & 0.408141 & -1.353195 & 5.863055 \\ \mathrm{C} & -0.831936 & -0.235339 & 7.562162 \\ \mathrm{C} & -2.547939 & -0.402802 & 3.388344 \\ \mathrm{C} & -2.763215 & 1.922712 & 2.916865 \\ \mathrm{H} & 2.804726 & 2.634679 & 4.684074 \\ \mathrm{H} & 2.125429 & 1.441076 & 5.830600 \\ \mathrm{H} & 2.992335 & 0.884943 & 4.370722 \\ \mathrm{H} & 1.622170 & 2.900684 & 2.524223 \\ \mathrm{H} & 1.861623 & 1.152442 & 2.226072 \\ \mathrm{H} & 0.212440 & 1.835644 & 2.246982 \\ \mathrm{H} & 1.263665 & -1.494293 & 6.534253 \\ \mathrm{H} & 0.765646 & -1.216615 & 4.841366 \\ \mathrm{H} & -0.238895 & -2.237376 & 5.913771 \\ \mathrm{H} & -0.011826 & -0.369419 & 8.277353 \\ \mathrm{H} & -1.543613 & -1.063174 & 7.664660 \\ \mathrm{H} & -1.335909 & 0.710726 & 7.761086 \\ \mathrm{H} & -2.004106 & -1.090770 & 4.036244 \\ \mathrm{H} & -2.345568 & -0.646070 & 2.338517\end{array}$




$\begin{array}{lrrr}\mathrm{H} & -3.623393 & -0.491748 & 3.582169 \\ \mathrm{H} & -2.584194 & 1.763244 & 1.846603 \\ \mathrm{H} & -3.842468 & 1.897965 & 3.109086 \\ \mathrm{H} & -2.361180 & 2.891522 & 3.216694 \\ \mathrm{O} & -1.293154 & 2.932225 & 5.945939 \\ \mathrm{C} & -2.631011 & 3.100218 & 6.432853 \\ \mathrm{C} & -0.454743 & 4.053002 & 6.258913 \\ \mathrm{H} & -3.092932 & 3.988884 & 5.986330 \\ \mathrm{H} & -3.196823 & 2.212513 & 6.146319 \\ \mathrm{H} & -2.633302 & 3.203544 & 7.524719 \\ \mathrm{H} & -0.863566 & 4.970514 & 5.819402 \\ \mathrm{H} & -0.368120 & 4.176714 & 7.344935 \\ \mathrm{H} & 0.527925 & 3.852302 & 5.831452\end{array}$

$\left[\mathrm{Li}\left(\mathrm{H}_{2} \mathrm{~N}-\mathrm{C}_{2} \mathrm{H}_{4}-\mathrm{NH}_{2}\right)\right]^{+}$

13

scf done: -197.940016

$\begin{array}{cccc}\mathrm{Li} & 0.675664 & -0.882692 & 1.464980 \\ \mathrm{~N} & 1.573700 & -0.324624 & 3.168447 \\ \mathrm{C} & 0.440345 & 0.329408 & 3.892472 \\ \mathrm{C} & -0.850496 & -0.461556 & 3.681881 \\ \mathrm{~N} & -1.154771 & -0.579644 & 2.222423 \\ \mathrm{H} & 2.366140 & 0.315704 & 3.124416 \\ \mathrm{H} & 1.911132 & -1.117778 & 3.716347 \\ \mathrm{H} & 0.329458 & 1.341856 & 3.488462 \\ \mathrm{H} & 0.639630 & 0.428905 & 4.965082 \\ \mathrm{H} & -1.667542 & 0.013836 & 4.235524 \\ \mathrm{H} & -0.737148 & -1.476257 & 4.079509 \\ \mathrm{H} & -1.873432 & -1.288883 & 2.079513 \\ \mathrm{H} & -1.579363 & 0.289486 & 1.894528\end{array}$

$\left.\mathrm{Li}\left(\mathrm{O}_{4} \mathrm{C}_{8} \mathrm{H}_{16}\right)\right]^{+}$ 29

scf done: -622.788707

$\begin{array}{rrrr}\mathrm{Li} & 0.703959 & -0.180981 & 0.142960 \\ \mathrm{O} & -0.797689 & -0.409170 & 1.461589 \\ \mathrm{C} & -0.288046 & -0.209166 & 2.790992 \\ \mathrm{C} & 0.620273 & 1.011764 & 2.714642 \\ \mathrm{O} & 1.561987 & 0.854808 & 1.636141 \\ \mathrm{C} & 2.825116 & 0.251183 & 1.962993 \\ \mathrm{C} & 3.496205 & -0.065965 & 0.632329 \\ \mathrm{O} & 2.586723 & -0.794262 & -0.214481 \\ \mathrm{C} & 2.635441 & -2.228747 & -0.131915 \\ \mathrm{C} & 1.405114 & -2.734388 & -0.874519 \\ \mathrm{O} & 0.228434 & -2.061003 & -0.387656 \\ \mathrm{C} & -0.472277 & -2.689106 & 0.699228 \\ \mathrm{C} & -1.470896 & -1.657209 & 1.207954 \\ \mathrm{H} & 0.264765 & -1.098421 & 3.124027 \\ \mathrm{H} & -1.112790 & -0.030012 & 3.491936 \\ \mathrm{H} & 1.136019 & 1.179036 & 3.666299 \\ \mathrm{H} & 0.036802 & 1.903395 & 2.471745\end{array}$

$\begin{array}{rrrr}\mathrm{H} & 3.440568 & 0.947818 & 2.545649 \\ \mathrm{H} & 2.668850 & -0.657909 & 2.559946 \\ \mathrm{H} & 4.426215 & -0.624464 & 0.783189 \\ \mathrm{H} & 3.726174 & 0.857526 & 0.094991 \\ \mathrm{H} & 2.627377 & -2.549250 & 0.918930 \\ \mathrm{H} & 3.550711 & -2.606518 & -0.604197 \\ \mathrm{H} & 1.304992 & -3.820809 & -0.777948 \\ \mathrm{H} & 1.472847 & -2.482734 & -1.935919 \\ \mathrm{H} & -0.994222 & -3.587567 & 0.347372 \\ \mathrm{H} & 0.234466 & -2.982140 & 1.487651 \\ \mathrm{H} & -1.985597 & -2.016123 & 2.105656 \\ \mathrm{H} & -2.217622 & -1.440983 & 0.439783\end{array}$

MeLi

5

scf done: -47.409949

$\begin{array}{llll}\text { C } & 0.392692 & -0.000411 & 0.000108\end{array}$

$\begin{array}{llll}\mathrm{Li} & -1.592300 & 0.001065 & -0.000250\end{array}$

$\begin{array}{llll}\mathrm{H} & 0.810054 & 0.997387 & -0.206655\end{array}$

$\mathrm{H} \quad 0.809006 \quad-0.320611 \quad 0.967920$

$\mathrm{H} \quad 0.808900 \quad-0.678849 \quad-0.760824$

$\operatorname{MeLi}\left(\mathrm{OMe}_{2}\right)$

14

scf done: -202.481638

$\begin{array}{rrrr}\mathrm{Li} & -1.202910 & -0.003572 & 0.000346 \\ \mathrm{C} & -3.200894 & -0.000690 & -0.000030 \\ \mathrm{H} & -3.624265 & 1.018102 & -0.000278 \\ \mathrm{H} & -3.628122 & -0.507798 & -0.881569 \\ \mathrm{H} & -3.628464 & -0.507511 & 0.881507 \\ \mathrm{O} & 0.705969 & -0.001113 & 0.000493 \\ \mathrm{C} & 1.491160 & 1.195117 & 0.000363 \\ \mathrm{C} & 1.496030 & -1.194091 & 0.000212 \\ \mathrm{H} & 2.120944 & 1.238539 & -0.896610 \\ \mathrm{H} & 0.799098 & 2.039071 & 0.000619 \\ \mathrm{H} & 2.121436 & 1.238401 & 0.896997 \\ \mathrm{H} & 2.126001 & -1.234831 & -0.896757 \\ \mathrm{H} & 2.126471 & -1.234933 & 0.896845 \\ \mathrm{H} & 0.807456 & -2.040896 & 0.000345\end{array}$

$\mathrm{MeLi}\left(\mathrm{OMe}_{2}\right)_{2}$

23

scf done: -357.540860

$\begin{array}{cccc}\mathrm{Li} & 0.000407 & 0.678312 & 0.003638 \\ \mathrm{C} & 0.118589 & 2.708723 & 0.025955 \\ \mathrm{H} & -0.369936 & 3.162650 & 0.908732 \\ \mathrm{H} & 1.149569 & 3.108464 & 0.033263 \\ \mathrm{H} & -0.364577 & 3.180704 & -0.850292 \\ \mathrm{O} & -1.640592 & -0.351875 & -0.006614 \\ \mathrm{C} & -2.839492 & 0.430082 & 0.003662 \\ \mathrm{C} & -1.872462 & -1.755488 & -0.029590\end{array}$ 


$\begin{array}{rrrr}\mathrm{H} & -3.436579 & 0.200565 & 0.896106 \\ \mathrm{H} & -2.526298 & 1.474926 & 0.019939 \\ \mathrm{H} & -3.433976 & 0.227957 & -0.897078 \\ \mathrm{H} & -2.435084 & -2.071209 & 0.859528 \\ \mathrm{H} & -2.432622 & -2.042360 & -0.929954 \\ \mathrm{H} & -0.895745 & -2.242871 & -0.036261 \\ \mathrm{O} & 1.545029 & -0.593542 & -0.008590 \\ \mathrm{C} & 2.343032 & -0.411288 & -1.181855 \\ \mathrm{C} & 2.312933 & -0.478267 & 1.192621 \\ \mathrm{H} & 3.139582 & -1.165982 & -1.220743 \\ \mathrm{H} & 1.684105 & -0.536458 & -2.043306 \\ \mathrm{H} & 2.779069 & 0.594909 & -1.200999 \\ \mathrm{H} & 3.105733 & -1.237669 & 1.211457 \\ \mathrm{H} & 2.752365 & 0.523151 & 1.277062 \\ \mathrm{H} & 1.631673 & -0.646441 & 2.029078\end{array}$

$\mathrm{MeLi}\left(\mathrm{OMe}_{2}\right)_{3}$

32

scf done: -512.593109

$\begin{array}{cccc}\mathrm{Li} & 0.029915 & 0.085891 & 0.523340 \\ \mathrm{C} & 0.207242 & 0.364267 & 2.582428 \\ \mathrm{H} & 0.632506 & -0.490707 & 3.146295 \\ \mathrm{H} & 0.850140 & 1.224870 & 2.856976 \\ \mathrm{H} & -0.759892 & 0.573643 & 3.082110 \\ \mathrm{O} & -1.279269 & -1.375599 & -0.028871 \\ \mathrm{C} & -1.658880 & -2.237693 & 1.046278 \\ \mathrm{C} & -1.716444 & -1.831506 & -1.299285 \\ \mathrm{H} & -1.226825 & -3.238783 & 0.907903 \\ \mathrm{H} & -1.266696 & -1.780229 & 1.955421 \\ \mathrm{H} & -2.753385 & -2.320545 & 1.101096 \\ \mathrm{H} & -1.263348 & -2.802006 & -1.548663 \\ \mathrm{H} & -2.810798 & -1.935051 & -1.324403 \\ \mathrm{H} & -1.410303 & -1.085696 & -2.036002 \\ \mathrm{O} & -0.724787 & 1.681716 & -0.545054 \\ \mathrm{C} & -2.015297 & 2.015356 & -0.032639 \\ \mathrm{C} & 0.175803 & 2.787452 & -0.487055 \\ \mathrm{H} & -2.462373 & 2.828524 & -0.621531 \\ \mathrm{H} & -2.633426 & 1.120112 & -0.114646 \\ \mathrm{H} & -1.946934 & 2.310007 & 1.021861 \\ \mathrm{H} & -0.202316 & 3.622138 & -1.093843 \\ \mathrm{H} & 0.317256 & 3.116353 & 0.550313 \\ \mathrm{H} & 1.130552 & 2.444311 & -0.888314 \\ \mathrm{O} & 1.806871 & -0.233057 & -0.432090 \\ \mathrm{C} & 2.890281 & -0.478471 & 0.468555 \\ \mathrm{C} & 2.089436 & -0.620796 & -1.767499 \\ \mathrm{H} & 3.773940 & 0.102329 & 0.169075 \\ \mathrm{H} & 2.541769 & -0.170020 & 1.454684 \\ \mathrm{H} & 3.145982 & -1.547234 & 0.479667 \\ \mathrm{H} & 2.968361 & -0.085594 & -2.154667 \\ \mathrm{H} & 2.275561 & -1.702547 & -1.834115 \\ \mathrm{H} & 1.218118 & -0.364475 & -2.374051\end{array}$

$\mathrm{MeLi}\left(\mathrm{H}_{2} \mathrm{~N}-\mathrm{C}_{2} \mathrm{H}_{4}-\mathrm{NH}_{2}\right)$ 17

scf done: -238.000333

$\begin{array}{rrrr}\mathrm{C} & 0.314256 & 0.429067 & 4.102007 \\ \mathrm{C} & -0.906666 & -0.429473 & 3.757851 \\ \mathrm{~N} & -1.004459 & -0.600399 & 2.296304 \\ \mathrm{~N} & 1.529756 & -0.170793 & 3.521208 \\ \mathrm{Li} & 0.990446 & -0.873775 & 1.574141 \\ \mathrm{H} & 2.298365 & 0.493750 & 3.489095 \\ \mathrm{H} & 1.851888 & -0.960818 & 4.077124 \\ \mathrm{H} & 0.192203 & 1.425508 & 3.660604 \\ \mathrm{H} & 0.367829 & 0.565127 & 5.191972 \\ \mathrm{H} & -1.804386 & 0.016764 & 4.209906 \\ \mathrm{H} & -0.786070 & -1.425154 & 4.201388 \\ \mathrm{H} & -1.620505 & -1.370152 & 2.048544 \\ \mathrm{H} & -1.388640 & 0.232282 & 1.853385 \\ \mathrm{C} & 1.930761 & -1.471211 & -0.122714 \\ \mathrm{H} & 1.252011 & -1.583743 & -0.986989 \\ \mathrm{H} & 2.718120 & -0.768342 & -0.450059 \\ \mathrm{H} & 2.434050 & -2.448634 & -0.009252\end{array}$

Li(allyl)

9

scf done: -124.838776

$\begin{array}{rrrr}\mathrm{Li} & 0.711910 & 1.306719 & 1.346935 \\ \mathrm{C} & -0.147007 & -0.538275 & 1.851323 \\ \mathrm{C} & 1.155542 & -0.418312 & 2.360919 \\ \mathrm{C} & 1.669468 & 0.660751 & 3.097277 \\ \mathrm{H} & 2.705068 & 0.661117 & 3.417794 \\ \mathrm{H} & 0.990850 & 1.267585 & 3.704865 \\ \mathrm{H} & 1.891660 & -1.123985 & 1.966772 \\ \mathrm{H} & -0.429508 & -1.408452 & 1.269714 \\ \mathrm{H} & -0.971200 & -0.027044 & 2.358743\end{array}$

$\mathrm{Li}($ allyl $)\left(\mathrm{OMe}_{2}\right)$

18

scf done: -279.909992

$\begin{array}{cccc}\mathrm{C} & -0.138264 & -0.803841 & 2.165477 \\ \mathrm{C} & 1.231420 & -0.657086 & 2.419988 \\ \mathrm{C} & 1.839927 & 0.283973 & 3.263904 \\ \mathrm{Li} & 0.507716 & 1.215098 & 1.869734 \\ \mathrm{H} & 2.919261 & 0.305226 & 3.368715 \\ \mathrm{H} & 1.275210 & 0.698327 & 4.103968 \\ \mathrm{H} & 1.923194 & -1.181891 & 1.753481 \\ \mathrm{H} & -0.488516 & -1.565623 & 1.477152 \\ \mathrm{H} & -0.864612 & -0.475342 & 2.914998 \\ \mathrm{O} & -0.150432 & 2.917693 & 1.369315 \\ \mathrm{C} & 0.521120 & 4.138865 & 1.689334 \\ \mathrm{H} & -0.122113 & 4.777721 & 2.308298 \\ \mathrm{H} & 1.421392 & 3.873959 & 2.245501\end{array}$




$\begin{array}{rrrr}\mathrm{H} & 0.797420 & 4.675643 & 0.772576 \\ \mathrm{C} & -1.353882 & 3.106925 & 0.620201 \\ \mathrm{H} & -2.071962 & 3.707398 & 1.194110 \\ \mathrm{H} & -1.137035 & 3.606748 & -0.332804 \\ \mathrm{H} & -1.773121 & 2.117447 & 0.430306\end{array}$

$\mathrm{Li}($ allyl $)\left(\mathrm{OMe}_{2}\right)_{2}$ 27

scf done: -434.966309

$\begin{array}{cccc}\mathrm{C} & -0.541179 & -0.543251 & 2.542516 \\ \mathrm{C} & 0.849483 & -0.638186 & 2.415334 \\ \mathrm{C} & 1.832242 & 0.191627 & 2.971464 \\ \mathrm{Li} & 0.360372 & 1.334709 & 1.793685 \\ \mathrm{O} & -0.230987 & 3.069935 & 2.560810 \\ \mathrm{C} & 0.349590 & 3.631652 & 3.737581 \\ \mathrm{C} & -1.601729 & 3.427919 & 2.389601 \\ \mathrm{H} & 2.881929 & -0.010599 & 2.784972 \\ \mathrm{H} & 1.613831 & 0.755402 & 3.880556 \\ \mathrm{H} & 1.204568 & -1.334913 & 1.648871 \\ \mathrm{H} & -1.184163 & -1.273748 & 2.061664 \\ \mathrm{H} & -0.978440 & -0.017845 & 3.394075 \\ \mathrm{H} & -1.707649 & 4.518592 & 2.313852 \\ \mathrm{H} & -1.942190 & 2.961051 & 1.464388 \\ \mathrm{H} & -2.206645 & 3.059675 & 3.228496 \\ \mathrm{H} & 0.313886 & 4.728543 & 3.694807 \\ \mathrm{H} & -0.178870 & 3.285959 & 4.635897 \\ \mathrm{H} & 1.385912 & 3.294225 & 3.773769 \\ \mathrm{O} & 0.343199 & 1.742845 & -0.149656 \\ \mathrm{C} & 0.079679 & 0.676573 & -1.062316 \\ \mathrm{H} & 1.012107 & 0.172968 & -1.349763 \\ \mathrm{H} & -0.570744 & -0.027421 & -0.541778 \\ \mathrm{H} & -0.420283 & 1.059475 & -1.962201 \\ \mathrm{C} & 1.214467 & 2.734967 & -0.685158 \\ \mathrm{H} & 2.193874 & 2.302598 & -0.930609 \\ \mathrm{H} & 0.778999 & 3.184693 & -1.587907 \\ \mathrm{H} & 1.336310 & 3.502206 & 0.081184\end{array}$

$\mathrm{Li}($ allyl $)\left(\mathrm{OMe}_{2}\right)_{3}$ bridged 36

scf done: -590.008137

$\begin{array}{rrrl}\mathrm{C} & -0.394986 & -0.697606 & 2.525509 \\ \mathrm{C} & 0.946134 & -0.573879 & 2.926468 \\ \mathrm{C} & 1.527480 & 0.345759 & 3.796783 \\ \mathrm{Li} & 0.395808 & 1.314146 & 1.890339 \\ \mathrm{O} & -0.852126 & 1.643822 & -0.031224 \\ \mathrm{C} & -0.736547 & 2.769735 & -0.888806 \\ \mathrm{C} & -1.812252 & 0.693933 & -0.482134 \\ \mathrm{O} & -0.457076 & 2.956502 & 2.784659 \\ \mathrm{C} & -1.866866 & 3.155432 & 2.720922 \\ \mathrm{C} & 0.132939 & 3.615173 & 3.903253 \\ \mathrm{H} & 2.590188 & 0.294781 & 4.014756\end{array}$

$\begin{array}{rrrr}\mathrm{H} & 0.915176 & 0.882321 & 4.520797 \\ \mathrm{H} & 1.653031 & -1.198474 & 2.368657 \\ \mathrm{H} & -0.684280 & -1.544004 & 1.908237 \\ \mathrm{H} & -1.187048 & -0.285696 & 3.155167 \\ \mathrm{H} & -2.102159 & 4.224946 & 2.625399 \\ \mathrm{H} & -2.223336 & 2.618849 & 1.842465 \\ \mathrm{H} & -2.355633 & 2.757903 & 3.620695 \\ \mathrm{H} & 0.007249 & 4.703704 & 3.816447 \\ \mathrm{H} & -0.322144 & 3.271805 & 4.841767 \\ \mathrm{H} & 1.191176 & 3.353860 & 3.909936 \\ \mathrm{H} & -1.545973 & 0.313555 & -1.479272 \\ \mathrm{H} & -1.799662 & -0.120549 & 0.243297 \\ \mathrm{H} & -2.815602 & 1.143190 & -0.532053 \\ \mathrm{H} & -0.443221 & 2.464021 & -1.903996 \\ \mathrm{H} & -1.687350 & 3.320546 & -0.949215 \\ \mathrm{H} & 0.037247 & 3.413382 & -0.469056 \\ \mathrm{O} & 2.009179 & 1.899229 & 0.669770 \\ \mathrm{C} & 2.452139 & 0.837163 & -0.172173 \\ \mathrm{H} & 3.022573 & 0.095724 & 0.402458 \\ \mathrm{H} & 1.559760 & 0.366740 & -0.586775 \\ \mathrm{H} & 3.078662 & 1.227521 & -0.986485 \\ \mathrm{C} & 3.094717 & 2.608687 & 1.260042 \\ \mathrm{H} & 3.671402 & 1.956842 & 1.927692 \\ \mathrm{H} & 3.751032 & 3.020022 & 0.479969 \\ \mathrm{H} & 2.668283 & 3.428067 & 1.841199\end{array}$

$\mathrm{Li}($ allyl $)\left(\mathrm{OMe}_{2}\right)_{3}$ terminal 36

scf done: -590.008930

$\begin{array}{rrrc}\mathrm{C} & -0.439312 & -0.848460 & 2.272267 \\ \mathrm{C} & 0.845330 & -0.197399 & 2.340517 \\ \mathrm{C} & 1.286320 & 0.833438 & 3.126930 \\ \mathrm{Li} & -1.357983 & 0.127390 & 0.601625 \\ \mathrm{O} & -2.120970 & 1.976672 & 0.893551 \\ \mathrm{C} & -1.652083 & 2.630998 & 2.079943 \\ \mathrm{C} & -3.397867 & 2.437669 & 0.474977 \\ \mathrm{O} & -0.240478 & 0.398747 & -1.087246 \\ \mathrm{C} & 0.487877 & 1.621964 & -1.208817 \\ \mathrm{C} & 0.533715 & -0.736116 & -1.473531 \\ \mathrm{O} & -2.863143 & -0.967286 & -0.218085 \\ \mathrm{C} & -3.487495 & -1.951934 & 0.606085 \\ \mathrm{C} & -3.351877 & -0.956950 & -1.552919 \\ \mathrm{H} & 2.285846 & 1.243140 & 3.013792 \\ \mathrm{H} & 0.691720 & 1.216695 & 3.955303 \\ \mathrm{H} & 1.574104 & -0.550627 & 1.599281 \\ \mathrm{H} & -0.385319 & -1.897622 & 1.955604 \\ \mathrm{H} & -1.059615 & -0.739582 & 3.171404 \\ \mathrm{H} & -3.370387 & 3.515231 & 0.260723 \\ \mathrm{H} & -3.662538 & 1.894721 & -0.434069 \\ \mathrm{H} & -4.157512 & 2.246901 & 1.246173 \\ \mathrm{H} & -1.574490 & 3.713073 & 1.906074\end{array}$




$\begin{array}{rrrr}\mathrm{H} & -2.340856 & 2.445307 & 2.914539 \\ \mathrm{H} & -0.668734 & 2.216189 & 2.315680 \\ \mathrm{H} & -3.343347 & -2.955203 & 0.182599 \\ \mathrm{H} & -3.004762 & -1.894716 & 1.582052 \\ \mathrm{H} & -4.563392 & -1.749931 & 0.700957 \\ \mathrm{H} & -3.205089 & -1.935895 & -2.030771 \\ \mathrm{H} & -4.422562 & -0.708210 & -1.578050 \\ \mathrm{H} & -2.782893 & -0.201015 & -2.097034 \\ \mathrm{H} & 1.434997 & -0.821210 & -0.854107 \\ \mathrm{H} & -0.089381 & -1.618993 & -1.322062 \\ \mathrm{H} & 0.820332 & -0.662581 & -2.531717 \\ \mathrm{H} & 1.369599 & 1.614540 & -0.555947 \\ \mathrm{H} & 0.799417 & 1.779320 & -2.250560 \\ \mathrm{H} & -0.184437 & 2.422502 & -0.898734\end{array}$

\section{$\mathrm{Li}\left(\mathrm{PH}_{2} \mathrm{BH}_{3}\right)$}

8

scf done: -376.769644565

$\begin{array}{rrrr}\mathrm{P} & 0.045037 & 0.103468 & -0.084894 \\ \mathrm{~B} & -0.076235 & -0.147791 & 1.914606 \\ \mathrm{H} & 1.414833 & 0.343459 & -0.337876 \\ \mathrm{H} & -0.441082 & 1.410472 & -0.315681 \\ \mathrm{Li} & -0.999107 & -1.736682 & 0.982467 \\ \mathrm{H} & 0.429605 & -1.267154 & 2.102374 \\ \mathrm{H} & 0.412928 & 0.687766 & 2.617651 \\ \mathrm{H} & -1.294812 & -0.274864 & 2.121954\end{array}$

$\mathrm{Li}\left(\mathrm{PH}_{2} \mathrm{BH}_{3}\right)\left(\mathrm{OMe}_{2}\right)_{3}$ 35

scf done: -1304.08884726

$\begin{array}{crrc}\mathrm{P} & 0.210884 & -0.080420 & 0.835641 \\ \mathrm{Li} & -0.962155 & -1.640985 & -0.732760 \\ \mathrm{~B} & -0.909773 & -0.041646 & 2.503930 \\ \mathrm{H} & 1.545888 & -0.366413 & 1.236094 \\ \mathrm{H} & 0.461347 & 1.273590 & 0.482121 \\ \mathrm{H} & -1.053530 & -1.215499 & 2.825331 \\ \mathrm{H} & -0.388069 & 0.611953 & 3.379842 \\ \mathrm{H} & -1.980571 & 0.429235 & 2.145541 \\ \mathrm{O} & -0.609912 & -1.460301 & -2.679096 \\ \mathrm{O} & -0.586648 & -3.528935 & -0.203885 \\ \mathrm{O} & -2.923202 & -1.351837 & -0.596191 \\ \mathrm{C} & -1.554756 & -1.687882 & -3.721672 \\ \mathrm{C} & 0.614814 & -0.884866 & -3.140646 \\ \mathrm{C} & -0.188071 & -3.838885 & 1.139274 \\ \mathrm{C} & -0.269544 & -4.567504 & -1.124335 \\ \mathrm{C} & -3.361262 & 0.004412 & -0.746811 \\ \mathrm{C} & -3.597411 & -2.014550 & 0.484109 \\ \mathrm{H} & -1.161885 & -2.408082 & -4.452340 \\ \mathrm{H} & -2.457722 & -2.085996 & -3.256063 \\ \mathrm{H} & -1.794516 & -0.749237 & -4.238883 \\ \mathrm{H} & 1.123611 & -1.568920 & -3.832821\end{array}$

$\begin{array}{cccc}\mathrm{H} & 0.422487 & 0.069857 & -3.646972 \\ \mathrm{H} & 1.233595 & -0.708886 & -2.259814 \\ \mathrm{H} & 0.812252 & -4.758437 & -1.139047 \\ \mathrm{H} & -0.793635 & -5.495024 & -0.857056 \\ \mathrm{H} & -0.591638 & -4.238202 & -2.113444 \\ \mathrm{H} & 0.898462 & -3.984948 & 1.188165 \\ \mathrm{H} & -0.472905 & -2.995492 & 1.770459 \\ \mathrm{H} & -0.694901 & -4.751007 & 1.480693 \\ \mathrm{H} & -3.371732 & -1.517391 & 1.433820 \\ \mathrm{H} & -4.680245 & -2.019192 & 0.302949 \\ \mathrm{H} & -3.227337 & -3.040740 & 0.504637 \\ \mathrm{H} & -3.181504 & 0.568670 & 0.174698 \\ \mathrm{H} & -2.782564 & 0.441344 & -1.563206 \\ \mathrm{H} & -4.429116 & 0.028668 & -1.001992\end{array}$

$\mathrm{LiCuCN}\left(\mathrm{C}\left(\mathrm{SiH}_{3}\right) \mathrm{CCHMe}\right)$ 16

scf done: -2186.911762

$\begin{array}{cccc}\mathrm{C} & -0.140783 & -0.477736 & 1.976584 \\ \mathrm{Cu} & -1.783445 & -1.473405 & 1.642588 \\ \mathrm{C} & -3.395587 & -1.911560 & 2.536424 \\ \mathrm{~N} & -4.029706 & -1.808557 & 3.523521 \\ \mathrm{C} & -0.286073 & -0.080337 & 3.197675 \\ \mathrm{C} & -0.529946 & 0.270172 & 4.479351 \\ \mathrm{C} & 0.118255 & -0.434413 & 5.668793 \\ \mathrm{Si} & 1.283197 & -0.126745 & 0.834538 \\ \mathrm{H} & -0.897992 & 1.285079 & 4.655659 \\ \mathrm{H} & 0.784024 & 0.573916 & -0.377593 \\ \mathrm{H} & 2.335559 & 0.714618 & 1.469615 \\ \mathrm{H} & 1.898027 & -1.409009 & 0.401799 \\ \mathrm{H} & 1.043136 & 0.071097 & 5.975969 \\ \mathrm{H} & -0.538909 & -0.447739 & 6.547484 \\ \mathrm{H} & 0.378059 & -1.468922 & 5.422952 \\ \mathrm{Li} & -2.517348 & -0.726735 & 4.268590\end{array}$

$\mathrm{LiCuCN}\left(\mathrm{C}\left(\mathrm{SiH}_{3}\right) \mathrm{CCHMe}\right)\left(\mathrm{OMe}_{2}\right)_{3}$ 43 scf done: -2652.090062

$\begin{array}{cccc}\mathrm{C} & -6.017936 & 2.733380 & 3.746422 \\ \mathrm{Cu} & -5.788889 & 0.959892 & 4.339811 \\ \mathrm{C} & -6.741571 & -1.028792 & 6.050230 \\ \mathrm{C} & -7.731464 & -1.226227 & 6.929762 \\ \mathrm{C} & -8.985141 & -2.034588 & 6.636343 \\ \mathrm{C} & -5.802792 & -0.783619 & 5.189632 \\ \mathrm{Si} & -4.462168 & -2.032106 & 4.843938 \\ \mathrm{Li} & -8.277512 & 1.096185 & 6.511520 \\ \mathrm{O} & -6.980929 & 2.369914 & 7.353318 \\ \mathrm{C} & -7.175338 & 3.777872 & 7.147311 \\ \mathrm{C} & -5.610684 & 2.060497 & 7.642453 \\ \mathrm{O} & -9.259203 & 1.457859 & 4.813587 \\ \mathrm{C} & -9.139773 & 0.641056 & 3.639706\end{array}$




$\begin{array}{cccc}\mathrm{C} & -9.663459 & 2.796326 & 4.484972 \\ \mathrm{O} & -9.802607 & 1.410487 & 7.807227 \\ \mathrm{C} & -11.174245 & 1.152177 & 7.505924 \\ \mathrm{C} & -9.561466 & 1.534459 & 9.209539 \\ \mathrm{H} & -7.528614 & -1.015608 & 7.983118 \\ \mathrm{H} & -9.894176 & -1.539618 & 7.001016 \\ \mathrm{H} & -9.102504 & -2.205291 & 5.561998 \\ \mathrm{H} & -8.943633 & -3.019856 & 7.119690 \\ \mathrm{H} & -6.786186 & 4.338816 & 8.006668 \\ \mathrm{H} & -6.682175 & 4.102172 & 6.224856 \\ \mathrm{H} & -8.250864 & 3.946191 & 7.070118 \\ \mathrm{H} & -5.310545 & 2.547191 & 8.579850 \\ \mathrm{H} & -5.532898 & 0.977831 & 7.740225 \\ \mathrm{H} & -4.960800 & 2.395419 & 6.826403 \\ \mathrm{H} & -10.599772 & 2.773976 & 3.912197 \\ \mathrm{H} & -9.834746 & 3.322334 & 5.426033 \\ \mathrm{H} & -8.879276 & 3.303702 & 3.913040 \\ \mathrm{H} & -10.122509 & 0.531159 & 3.162293 \\ \mathrm{H} & -8.430711 & 1.088563 & 2.935428 \\ \mathrm{H} & -8.768158 & -0.333357 & 3.955687 \\ \mathrm{H} & -4.458989 & -2.398154 & 3.401218 \\ \mathrm{H} & -3.126613 & -1.453065 & 5.157482 \\ \mathrm{H} & -4.616568 & -3.286880 & 5.637620 \\ \mathrm{H} & -10.162895 & 2.350357 & 9.631560 \\ \mathrm{H} & -9.807778 & 0.598428 & 9.727892 \\ \mathrm{H} & -8.501815 & 1.759552 & 9.331095 \\ \mathrm{H} & -11.508861 & 0.223857 & 7.987251 \\ \mathrm{H} & -11.804750 & 1.983065 & 7.849355 \\ \mathrm{H} & -11.249823 & 1.052662 & 6.422983 \\ \mathrm{~N} & -6.286143 & 3.845000 & 3.486090\end{array}$


S4 : Scan geometries (regular Li)

\section{$\operatorname{Li}($ allyl $)\left(\mathrm{OMe}_{2}\right)$}

18

param $=68.106201 \mathrm{E}=-279.910160$

C - $0.420215-1.3818602 .473603$

C $0.760765 \quad-0.705107 \quad 2.136874$

C 0.9706660 .6812902 .122225

Li -0.759364 $0.127288 \quad 1.000439$

O - $2.043412 \quad 0.783528 \quad-0.229139$

C -3.247059 $0.084203 \quad-0.558711$

C - $1.9005282 .027624-0.921038$

H 1.9338281 .0852461 .829667

H $0.364177 \quad 1.3268972 .763715$

H $1.530598-1.3077141 .645927$

H -0.460606 -2.4649082 .431375$

H -1.142922 $-0.908693 \quad 3.144323$

$\mathrm{H}-2.7295502 .701500-0.671010$

H -0.956986 2.468512 -0.595988

H -1.876929 $1.861089-2.005283$

$\mathrm{H}-4.124277 \quad 0.686014-0.289985$

H $-3.273904 \quad-0.145599-1.631253$

H -3.246358 -0.8431150 .016111$ 18

param $=73.106201 \mathrm{E}=-279.909201$

C $-0.395320-1.3689712 .438562$

$\begin{array}{llll}\text { C } 0.808248 & -0.699420 & 2.158238\end{array}$

C $0.986587 \quad 0.6867602 .117453$

Li $-0.817008 \quad 0.042964 \quad 0.999351$

O $-2.076654 \quad 0.754703 \quad-0.224598$

C $-3.2962110 .099443-0.584153$

C - $1.8844612 .005781-0.892156$

H 1.9429551 .1153261 .837931

H $0.331803 \quad 1.3364542 .704703$

H $1.607531-1.3034221 .720234$

$\mathrm{H}-0.418434 \quad-2.4537932 .463146$

H -1.126651 -0.8830293 .094007$

H -2.695975 $2.700612-0.642241$

H $-0.9325622 .410590-0.545025$

$\mathrm{H}-1.8494821 .857114-1.978623$

$\mathrm{H}-4.158326 \quad 0.724020-0.318546$

H $-3.313725 \quad-0.111889-1.660682$

H $-3.334391 \quad-0.837049 \quad-0.025747$

18

param $=78.106201 \mathrm{E}=-279.906571$

C - $0.363895 \quad-1.356848 \quad 2.422352$

C $0.853056-0.6888922 .174238$

C 1.0181840 .6936412 .129024
Li -0.896443 -0.040505 0.998191

O -2.121264 $0.725807 \quad-0.226495$

C -3.352770 $0.116577 \quad-0.624339$

C $-1.874545 \quad 1.982202 \quad-0.866887$

H 1.9684691 .1374741 .852233

H 0.3299831 .3456612 .673008

H $1.667472-1.2922091 .764573$

H - $0.369637-2.4402892 .501368$

H - $1.085817 \quad-0.8655643 .087610$

H -2.669544 $2.697492-0.622113$

H -0.918410 $2.350096-0.491053$

H - $1.8193981 .851126-1.954672$

$\mathrm{H}-4.200140 \quad 0.764340-0.367228$

H -3.352513 $-0.076469-1.704380$

H -3.434866 $-0.827446-0.083578$

18

param $=83.106201 \mathrm{E}=-279.903076$

C - $0.297806-1.3552512 .450475$

C $0.890339-0.6376542 .157239$

C 1.0164390 .7420052 .119093

$\mathrm{Li}-1.062033-0.2004991 .026346$

O -2.204014 $0.655370-0.216337$

C -3.454318 $0.163601 \quad-0.705745$

C - $1.8153721 .905576-0.800480$

H $1.938822 \quad 1.217857 \quad 1.802940$

H 0.3037481 .3789642 .647787

H $1.713335-1.213962 \quad 1.725547$

H - $0.231871 \quad-2.4339442 .572118$

$\mathrm{H}-0.982011 \quad-0.890842 \quad 3.174801$

H -2.562499 $2.677223-0.577816$

$\mathrm{H}-0.8561282 .178852-0.356959$

$\mathrm{H}-1.7060601 .799616-1.886750$

$\mathrm{H}-4.258967 \quad 0.874630-0.481108$

H -3.402508 $-0.002168-1.788949$

H $-3.651172-0.783180-0.200350$

18

param $=88.106201 \mathrm{E}=-279.899819$

C $-0.242035-1.3461912 .462326$

C $0.894632-0.5581122 .097263$

C 1.0094710 .8139772 .149896

Li - $1.286611-0.3514301 .100416$

O -2.292739 $0.587518-0.194552$

C -3.546790 $0.220566-0.774916$

C - $1.742033 \quad 1.794740-0.743092$

H $1.895567 \quad 1.3230021 .784291$ 
H 0.3092181 .4149312 .732765

H $1.693423 \quad-1.086881 \quad 1.568154$

H $-0.090038 \quad-2.4211612 .547556$

H $-0.837695 \quad-0.952343 \quad 3.298774$

H -2.424409 $2.635023-0.567002$

H $-0.7930591 .971531 \quad-0.232021$

$\mathrm{H}-1.5699621 .676345 \quad-1.819667$

H -4.291655 $1.007580-0.604411$

H -3.433952 $0.048741-1.852455$

H -3.873409 $-0.701639-0.291473$ 18

param $=93.106201 \mathrm{E}=-279.895130$ C - $0.247206-1.182147 \quad 2.436541$

C $0.864089-0.378323 \quad 1.959452$

C $1.097648 \quad 0.957025 \quad 2.117054$

Li - $1.693972-0.816286 \quad 1.076525$

$\begin{array}{llll}\mathrm{O}-2.444801 & 0.343374 & -0.199632\end{array}$

C -3.651172 $0.305206-0.963115$

C $-1.645529 \quad 1.516511 \quad-0.452583$

H $1.9670891 .435282 \quad 1.675663$

H 0.4759701 .5721462 .767616

H $1.577608 \quad-0.9102091 .320047$

H $-0.005030-2.242443 \quad 2.556095$

H $-0.704933 \quad-0.7953763 .358767$

H -2.215036 $2.417113-0.194332$

H $-0.752120 \quad 1.4462090 .176229$

$\mathrm{H}-1.357718 \quad 1.549267 \quad-1.510059$

H $-4.282079 \quad 1.170322-0.725013$

H -3.424433 $0.301584-2.036339$

$\begin{array}{lll}\text { H }-4.180450 & -0.613059 & -0.701066\end{array}$

18

param $=98.106201 \mathrm{E}=-279.894195$

C - $0.254800-1.132512 \quad 2.395767$

$\begin{array}{llll}\mathrm{C} & 0.885127 & -0.347266 & 1.948322\end{array}$

C $1.148077 \quad 0.977223 \quad 2.132406$

Li $-1.754457 \quad-0.878905 \quad 1.063333$

$\begin{array}{llll}\mathrm{O}-2.483591 & 0.301367 & -0.203104\end{array}$

C -3.675258 $0.313906-0.989473$

C - $1.649782 \quad 1.460387-0.409964$

H $2.0346691 .442529 \quad 1.711662$

H 0.5251561 .5991622 .775133

H $1.598724-0.887984 \quad 1.316585$

H $-0.018289-2.1930892 .535911$

H $-0.715657 \quad-0.737093 \quad 3.313852$

H -2.201639 $2.367873-0.138019$

$\begin{array}{llll}\mathrm{H}-0.768780 & 1.353521 & 0.230927\end{array}$

H - $1.342195 \quad 1.513280-1.461004$

$\begin{array}{llll}\mathrm{H}-4.289417 & 1.187840 & -0.739887\end{array}$

$\begin{array}{llll}\mathrm{H}-3.428085 & 0.333541 & -2.058010\end{array}$

H -4.231879 $\quad-0.597587 \quad-0.762585$ 18 param $=103.106201 \mathrm{E}=-279.893177$

C $-0.259664-1.089127 \quad 2.347960$

$\begin{array}{llll}\text { C } 0.910908 & -0.322327 & 1.943792\end{array}$

C 1.1935490 .9929592 .151857

Li -1.799755 -0.930945 1.047290

$\begin{array}{llll}\text { O - }-2.518248 & 0.268570 & -0.205283\end{array}$

C $-3.6986910 .322056-1.006157$

C - $1.655917 \quad 1.412752 \quad-0.379455$

H $2.100195 \quad 1.446732 \quad 1.762371$

H $0.559542 \quad 1.6214832 .777067$

H $1.633970-0.871515 \quad 1.330627$

H $-0.031284 \quad-2.1496962 .510881$

H $-0.733351 \quad-0.685173 \quad 3.257125$

H - $2.1915412 .326781-0.097315$

H $-0.785265 \quad 1.275736 \quad 0.269268$

H -1.334019 1.478197 - 1.425456

H $-4.2970991 .204474-0.748085$

H -3.437441 $0.356303-2.071012$

H $-4.277965 \quad-0.581063-0.803623$

18

param $=108.106201 \mathrm{E}=-279.892005$

C $-0.262433-1.049665 \quad 2.295953$

C $0.938378-0.301476 \quad 1.944123$

C $1.234868 \quad 1.005587 \quad 2.175443$

Li $-1.834414 \quad-0.9762021 .029869$

$\begin{array}{llll}\mathrm{O}-2.548067 & 0.241683 & -0.207242\end{array}$

C -3.721169 $0.329265-1.015376$

C $-1.661962 \quad 1.371481 \quad-0.359169$

H $2.1623691 .448066 \quad 1.823900$

H $0.585261 \quad 1.6409872 .777195$

H $1.675274-0.8593531 .356091$

H - $0.045314 \quad-2.110136 \quad 2.482704$

H - $0.756136-0.636702 \quad 3.191937$

H - $2.182221 \quad 2.291450-0.067837$

H $-0.798990 \quad 1.2085320 .293102$

H - $1.331751 \quad 1.445038-1.402005$

H -4.304318 $1.219652-0.749609$

H -3.451956 $0.372960-2.077956$

H -4.319494 $-0.564971-0.829269$

27

\section{$\operatorname{Li}($ allyl $)\left(\mathrm{OMe}_{2}\right)_{2}$}

param $=67.770699 \mathrm{E}=-434.966374$

C $-0.881307 \quad-0.9414912 .935343$

C $0.226861 \quad-0.5538132 .173223$

C $0.678863 \quad 0.742183 \quad 1.891484$

Li - $1.431187 \quad 0.454453 \quad 1.307944$

$\begin{array}{llll}\mathrm{O}-2.157804 & -0.244111 & -0.406162\end{array}$

C $-2.0578640 .551882-1.584306$

C $-2.032019-1.643556-0.663590$

O $-2.672395 \quad 1.965426 \quad 1.664448$ 
C $-4.0361681 .647711 \quad 1.938758$

C $-2.246541 \quad 3.177528 \quad 2.286467$

H $1.564205 \quad 0.887471 \quad 1.281038$

H $0.435654 \quad 1.5601832 .572273$

H $0.691699-1.3495981 .581836$

H - $1.100420-1.9944663 .081874$

H - $1.292793 \quad-0.2650243 .687412$

H -4.696710 2.4480551 .578724

H -4.262099 $0.721031 \quad 1.409283$

H -4.192890 1.5025943 .015752

H - 2.8559844 .0210951 .935618

H - $2.3245263 .101943 \quad 3.379105$

H - 1.2040783 .3307532 .005897

H $-1.065454 \quad-1.866318-1.134486$

H -2.090516 -2.1463620 .302534$

H - $2.844335 \quad-1.985161 \quad-1.319088$

$\mathrm{H}-1.071864 \quad 0.431219 \quad-2.052479$

H -2.840246 $0.275506-2.304136$

H -2.192013 $1.591591 \quad-1.281400$

27

param $=72.770699 \mathrm{E}=-434.965655$

C $-0.896667 \quad-0.9146332 .897874$

C $0.260990 \quad-0.569806 \quad 2.182013$

C $0.723580 \quad 0.713715 \quad 1.884585$

Li - $1.490182 \quad 0.409537 \quad 1.338201$

$\begin{array}{llll}\text { O }-2.179771 & -0.256634 & -0.400291\end{array}$

C - $2.071584 \quad 0.561364-1.562540$

C $-2.016245-1.648378-0.678609$

O $-2.695343 \quad 1.958444 \quad 1.664303$

C $-4.062250 \quad 1.661947 \quad 1.947999$

C $-2.248050 \quad 3.166813 \quad 2.278718$

H $1.615458 \quad 0.853141 \quad 1.282636$

H $0.443047 \quad 1.5562732 .518993$

H $0.742118-1.3856991 .633440$

H - $1.111005-1.9595413 .103006$

H - $1.296518 \quad-0.212603 \quad 3.635172$

H -4.712784 2.4707381 .588878

H $-4.305434 \quad 0.736949 \quad 1.423077$

H -4.214643 1.5229663 .026395

H - $2.848415 \quad 4.017380 \quad 1.929363$

H -2.318260 3.0963693 .372195

H - 1.2058743 .3053921 .989198

H - $1.035376-1.840142 \quad-1.133173$

$\begin{array}{llll}\mathrm{H}-2.081617 & -2.168737 & 0.277654\end{array}$

H -2.807167 $-1.997032-1.356194$

H - $1.073755 \quad 0.468414 \quad-2.011478$

H -2.833126 0.281738 - 2.303184

H -2.233057 1.592749 - 1.244864

27

param $=77.770699 \mathrm{E}=-434.963736$

C $-0.924798-0.8969462 .875192$

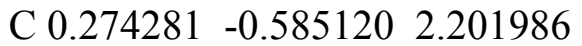

$\begin{array}{llll}C & 0.769101 & 0.681890 & 1.912054\end{array}$

Li - $1.586105 \quad 0.357324 \quad 1.356348$

$\begin{array}{llll}\text { O }-2.197279 & -0.279943 & -0.411299\end{array}$

C - $2.111816 \quad 0.568361-1.553682$

C $-1.955774-1.654988-0.716883$

O $-2.734854 \quad 1.949881 \quad 1.657433$

C $-4.099788 \quad 1.6952991 .989053$

C - $-2.234893 \quad 3.153700 \quad 2.240770$

H $1.672217 \quad 0.808303 \quad 1.324185$

H $0.457242 \quad 1.5452652 .501463$

H $0.762694-1.4168061 .684483$

H - $1.135616-1.9344573 .122487$

H $-1.303645 \quad-0.1811783 .612960$

H -4.739198 2.5158451 .637092

H -4.385451 $0.769156 \quad 1.487833$

$\mathrm{H}-4.221211 \quad 1.577267 \quad 3.073773$

H -2.821862 4.0158601 .897490

H -2.272879 3.0995993 .336625

H - $1.1985753 .258508 \quad 1.917617$

H $-0.957128 \quad-1.783613-1.154267$

$\begin{array}{llll}\mathrm{H}-2.012723 & -2.200136 & 0.225948\end{array}$

H - $2.713945-2.027933-1.418408$

H - $1.105551 \quad 0.529891 \quad-1.991576$

H -2.851061 $0.271706-2.310058$

H - $2.323315 \quad 1.583988-1.215254$

27

param $=82.770699 \mathrm{E}=-434.961312$

C $-0.936100 \quad-0.896853 \quad 2.848831$

C $0.291520 \quad-0.577812 \quad 2.213309$

C $0.829843 \quad 0.678052 \quad 1.992831$

Li - $1.712702 \quad 0.295115 \quad 1.370726$

$\begin{array}{lll}\mathrm{O}-2.211464 & -0.310818 & -0.428748\end{array}$

C $-2.161511 \quad 0.563454-1.553640$

C $-1.899401 \quad-1.666450-0.758739$

O $-2.789156 \quad 1.934144 \quad 1.649473$

C $-4.152388 \quad 1.7520632 .032499$

C - $2.214042 \quad 3.126847 \quad 2.187456$

H 1.7448990 .8069021 .424049

H 0.4939941 .5397612 .570302

H $0.781901-1.4023891 .685395$

H - $1.128686-1.9405423 .090888$

H - $1.288516 \quad-0.2071913 .625752$

H -4.764649 $2.593141 \quad 1.681179$

H -4.499295 $0.828973 \quad 1.564982$

H -4.241843 1.6653973 .123174

H - $2.7667874 .007677 \quad 1.835233$

H - $2.226092 \quad 3.1021253 .284731$

H - $1.1822863 .169748 \quad 1.836596$

H $-0.892258 \quad-1.735671-1.189441$

H - $1.936267 \quad-2.232109 \quad 0.172860$ 
H -2.633015 $-2.062219-1.473556$

$\mathrm{H}-1.1531630 .580074-1.988071$

$\mathrm{H}-2.883614 \quad 0.248131 \quad-2.318829$

H -2.420852 $1.561172-1.195877$

27

param $=87.770699 \mathrm{E}=-434.959106$

C - $0.863098 \quad-0.8690472 .815183$

C $0.365828-0.5104482 .180364$

C $0.955148 \quad 0.730479 \quad 2.078824$

Li - $1.828788 \quad 0.241796 \quad 1.394093$

O - $2.260553-0.348135-0.420244$

C - $2.2148390 .531114-1.542186$

C - $1.936258-1.700504-0.754448$

O $-2.836651 \quad 1.920037 \quad 1.638140$

C $-4.229172 \quad 1.8338551 .938595$

C - $2.2037893 .052648 \quad 2.241367$

H $1.863571 \quad 0.8792621 .503919$

H 0.6355431 .5608042 .708322

H $0.830488-1.299707 \quad 1.578635$

H -1.022598 -1.9307453 .005984$

H -1.161704 -0.2482383 .669974$

H -4.755252 $2.728598 \quad 1.580622$

$\mathrm{H}-4.6184050 .953638 \quad 1.423509$

$\mathrm{H}-4.3877301 .7251663 .019411$

H -2.653110 3.9816591 .867077

H -2.300373 3.0126763 .333801

H - $1.1486023 .010237 \quad 1.968065$

H -0.929959 $-1.758187-1.188295$

$\mathrm{H}-1.963663 \quad-2.2695140 .175372$

H -2.668406 $-2.101546-1.467659$

$\mathrm{H}-1.2072580 .551273 \quad-1.977870$

$\mathrm{H}-2.937120 \quad 0.216713 \quad-2.307418$

$\mathrm{H}-2.475181 \quad 1.526843 \quad-1.179771$

27

param $=92.770699 \mathrm{E}=-434.957536$

C $-0.760220-0.8605712 .753685$

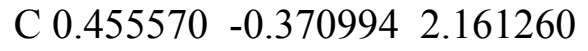

C $1.0640850 .852395 \quad 2.289262$

Li - $1.9412640 .158250 \quad 1.413211$

O $-2.334882 \quad-0.418291-0.412449$

C $-2.3519430 .468666-1.529578$

C - $1.984066-1.759298-0.766210$

O $-2.8638621 .874444 \quad 1.630601$

C -4.2762271 .9675441 .802531$

C - 2.1457142 .9227672 .293703

H 1.9585101 .1002151 .726169

H 0.7546301 .5639513 .054193

H $0.910611-1.0392531 .420125$

H -0.850220 -1.9486792 .801856$

H - $1.035023 \quad-0.3952423 .709206$

H -4.650623 2.9188191 .401874
$\mathrm{H}-4.727713 \quad 1.139898 \quad 1.251693$

H -4.545355 1.8902232 .864225

$\mathrm{H}-2.4308843 .897056 \quad 1.876318$

H -2.354585 2.9086743 .370770

H - 1.0833502 .7357182 .125340

H -0.993066 $-1.785327-1.236651$

$\mathrm{H}-1.960180 \quad-2.334572 \quad 0.159794$

H -2.729819 $-2.178350-1.454379$

H - $1.3633390 .511529-2.005132$

$\mathrm{H}-3.097214 \quad 0.144145 \quad-2.267915$

H -2.615790 $1.457010 \quad-1.150133$

27

param $=97.770699 \mathrm{E}=-434.956650$

C $-0.623535-0.8559062 .618107$

C $0.584826-0.1630542 .235191$

C 1.1267090 .9975382 .718442

Li - $1.925146 \quad 0.127912 \quad 1.346049$

$\begin{array}{llll}\text { O }-2.396080 & -0.478679 & -0.450477\end{array}$

C $-2.608600 \quad 0.357384-1.585838$

C -2.088475 $-1.832302-0.797881$

O $-2.799058 \quad 1.854292 \quad 1.593945$

C $-4.2052542 .078300 \quad 1.640587$

C - 2.0478452 .8256092 .338551

H 2.0285251 .4226162 .288089

H $0.740092 \quad 1.4757513 .617935$

H $1.108784-0.5948661 .373290$

H -0.599528 -1.9345732 .429244$

H $-0.966265 \quad-0.649193 \quad 3.640210$

$\mathrm{H}-4.4535323 .061801 \quad 1.219830$

H -4.683009 $1.297677 \quad 1.044728$

H -4.573669 2.0244382 .673555

H -2.185897 $3.822153 \quad 1.899679$

H -2.374836 2.8365413 .385819

$\mathrm{H}-0.9967942 .5290572 .287215$

$\mathrm{H}-1.191581 \quad-1.871494-1.429070$

$\mathrm{H}-1.898093 \quad-2.3622690 .135751$

H -2.932691 $-2.290147 \quad-1.329738$

$\mathrm{H}-1.7166920 .375456-2.225795$

H -3.467429 $0.003382-2.171612$

H -2.806859 $1.363297 \quad-1.212439$

27

param $=102.770699 \mathrm{E}=-434.956047$

C $-0.530127 \quad-0.811240 \quad 2.513404$

C $0.677653-0.042227 \quad 2.297365$

C 1.1582301 .0472622 .968300

Li -1.901294 $0.130763 \quad 1.274336$

O - $2.446053-0.510084-0.488973$

C - $2.749104 \quad 0.288361-1.630684$

C $-2.167131-1.875394-0.815233$

O $-2.762623 \quad 1.851515 \quad 1.566547$

C -4.158328 2.1348331 .563404 
C - $2.002157 \quad 2.7728192 .365730$

H $2.067942 \quad 1.5500682 .653574$

H 0.7002021 .3941123 .894112

H $1.262038 \quad-0.3417401 .418461$

H - $0.436467 \quad-1.8616302 .211547$

H -0.927815 -0.745932 3.535280

$\mathrm{H}-4.3488713 .135502 \quad 1.152913$

H -4.646188 1.3858360 .935928

$\mathrm{H}-4.5684762 .0791262 .580495$

H -2.078016 3.7832701 .943916

H -2.376494 2.7756603 .397066

H - 0.9625322 .4333192 .357666

H - $1.330055-1.936386-1.522246$

$\mathrm{H}-1.892503 \quad-2.3729890 .115194$

H -3.054069 -2.351262 - 1.253352

$\mathrm{H}-1.913053 \quad 0.278850 \quad-2.342137$

H -3.654590 $-0.079744-2.131235$

H -2.912048 $1.308057 \quad-1.278013$ 27

param $=107.770699 \mathrm{E}=-434.955536$

C -0.312249 $-0.740517 \quad 2.267767$

C $0.821046 \quad 0.1638992 .298154$

C $1.170441 \quad 1.1020523 .226260$

Li - $1.822593 \quad 0.172162 \quad 1.171553$

O $-2.586768-0.539801 \quad-0.492004$

C -2.804097 $0.198683-1.692401$

C - $2.422917-1.943334-0.721028$

O $-2.711112 \quad 1.844114 \quad 1.577636$

C -4.085802 2.186706 1.437083

C -2.004052 2.7043972 .487546

H $2.036202 \quad 1.742673 \quad 3.085681$

H $0.642531 \quad 1.1901524 .175485$

H 1.4606310 .1280631 .407720

H - $0.089749-1.6833231 .750888$

H $-0.737440 \quad-0.949953 \quad 3.259616$

H -4.192240 3.2023391 .032731

H -4.535420 $1.469686 \quad 0.747135$

$\mathrm{H}-4.6010272 .1300422 .405218$

H -2.015021 3.7350702 .110328

H -2.475499 $2.670773 \quad 3.477849$

$\mathrm{H}-0.9760102 .3374962 .559290$

H - $1.580895-2.125215-1.400616$

H -2.209981 -2.4020190 .244916$

H -3.340581 $-2.368059-1.148049$

$\mathrm{H}-1.9598840 .073840 \quad-2.383089$

H $-3.727868-0.129985-2.186671$

H -2.891575 1.250782 - 1.415634

27

param $=112.770699 \mathrm{E}=-434.955113$

C $-0.110605-0.616491 \quad 1.942980$

$\begin{array}{llll}\mathrm{C} & 0.922110 & 0.349879 & 2.268647\end{array}$
C $1.142915 \quad 1.0384243 .425050$

Li - 1.7727900 .2526661 .055702

O - $2.730152-0.546821 \quad-0.473774$

C $-2.800526 \quad 0.075737-1.755576$

C -2.640729 $-1.973673-0.553953$

O $-2.695985 \quad 1.849745 \quad 1.606711$

C -4.043203 $2.250672 \quad 1.380898$

C -2.016406 2.662913 2.579260

H 1.9425241 .7691973 .505618

H $0.570393 \quad 0.8342384 .329562$

H $1.588638 \quad 0.606390 \quad 1.436474$

H $0.227921-1.3647851 .213322$

H $-0.524731-1.1250832 .826905$

H -4.081436 3.2739190 .983512

$\mathrm{H}-4.474894 \quad 1.5583120 .655401$

$\mathrm{H}-4.621765 \quad 2.2061712 .313191$

$\mathrm{H}-1.959770 \quad 3.7000092 .224219$

H -2.556154 2.6316443 .534259

$\mathrm{H}-1.0107972 .2532852 .711092$

H - $1.753058-2.272929-1.124531$

H $-2.552000 \quad-2.3491290 .466100$

H -3.542391 $-2.383023-1.027309$

$\mathrm{H}-1.906501 \quad-0.154081-2.349888$

H -3.693556 $-0.259996-2.298771$

H -2.858984 $1.153535-1.591733$

27

param $=117.770699 \mathrm{E}=-434.954584$

C $-0.092891 \quad-0.536282 \quad 1.891781$

$\begin{array}{llll}\mathrm{C} & 0.946026 & 0.363113 & 2.361668\end{array}$

C 1.1074060 .9489193 .581593

Li - $1.756209 \quad 0.300981 \quad 0.982815$

O -2.698963 $-0.577487-0.502573$

C -3.003302 $0.006928-1.767030$

C $-2.502936-1.994276-0.576603$

O $-2.680390 \quad 1.887212 \quad 1.566933$

C -4.013856 $2.333631 \quad 1.347899$

C - 1.9733182 .6711682 .544974

H $1.920247 \quad 1.6433393 .773893$

H $0.465023 \quad 0.6985744 .425577$

H $1.673870 \quad 0.660814 \quad 1.597783$

Н $0.280034-1.2383781 .132181$

H $-0.566413 \quad-1.1054652 .708368$

H -4.020469 3.3584520 .952611

$\mathrm{H}-4.473158 \quad 1.658177 \quad 0.623271$

H -4.589826 2.3059462 .282399

H - 1.8716113 .7052682 .191338

H -2.520702 2.661112 3.495986

H -0.9876082 .2197282 .685213$

H - $1.693219-2.233494-1.276924$

H -2.223956 -2.3331750 .421562$

H -3.428938 $-2.488267 \quad-0.897554$ 
H -2.189673 $-0.169449-2.482749$

H $-3.936887 \quad-0.407503 \quad-2.169657$

H -3.120211 $1.081138-1.611391$

36

\section{$\mathrm{Li}($ allyl $)\left(\mathrm{OMe}_{2}\right)_{3}$}

param $=69.830299 \mathrm{E}=-590.008220$

C $-0.996624 \quad-0.9900902 .789173$

C $0.307656-0.6141902 .431840$

C $0.860775 \quad 0.6604542 .309801$

Li $-1.031609 \quad 0.245058 \quad 0.874830$

O - $2.1413331 .955493 \quad 1.109628$

C $-1.581503 \quad 3.2042761 .509401$

C -3.509119 $1.828277 \quad 1.491156$

$\begin{array}{llll}\mathrm{O}-0.045525 & 0.389123 & -1.025014\end{array}$

C $0.6933241 .578409-1.288689$

C $0.722825-0.786760-1.269420$

$\begin{array}{llll}\text { O }-2.623040 & -0.836879 & -0.303196\end{array}$

C - $3.265360-2.008172 \quad 0.192951$

C -3.067253 $-0.472194-1.603272$

H 1.9077560 .7752112 .044506

Н 0.4000691 .5111462 .810913

H $0.938021-1.4324062 .065097$

H - $1.222478-2.0436722 .929703$

H - $1.626656 \quad-0.2974993 .351129$

H -4.112536 2.6242351 .032423

$\mathrm{H}-3.847577 \quad 0.855261 \quad 1.136700$

$\mathrm{H}-3.613001 \quad 1.8787412 .583259$

H -2.100855 4.0338891 .009176

H - 1.6555963 .3346002 .597265

$\mathrm{H}-0.5292193 .1920961 .225719$

H $-3.062865-2.868238-0.461725$

$\mathrm{H}-2.851409-2.1869601 .185920$

$\mathrm{H}-4.353703 \quad-1.859794 \quad 0.256401$

H $-2.882140-1.282493-2.323612$

H $-4.143308-0.242814-1.601066$

H -2.498679 $0.409024-1.900123$

H $1.607488-0.816343-0.620474$

H $0.080712-1.640490-1.046406$

H $1.038197-0.828392-2.321491$

H $1.5391581 .671166-0.596043$

H $1.0556881 .582401-2.326561$

H $0.0124532 .419293-1.143470$

36

param $=74.830299 \mathrm{E}=-590.008069$

C - $0.909491 \quad-1.0205812 .668817$

C $0.397433-0.5542442 .408419$

C $0.892054 \quad 0.742558 \quad 2.410834$

Li $-1.088273 \quad 0.210931 \quad 0.847385$

O -2.161908 $1.946212 \quad 1.104586$

C - 1.5886783 .1922041 .495312
$\begin{array}{lll}\mathrm{C}-3.531301 & 1.838525 & 1.485613\end{array}$

O $-0.041760 \quad 0.353142 \quad-0.982310$

C $0.7112371 .532872-1.251568$

C $0.705674-0.834029-1.240138$

O -2.663830 $-0.816676-0.315491$

C $-3.305343-1.9876350 .183297$

C -3.108042 $-0.450185-1.614880$

H 1.9351920 .9356722 .178797

H 0.3510721 .5457142 .908799

H $1.087002-1.3143602 .023663$

H - $1.060858 \quad-2.0928982 .771553$

H - $1.577308 \quad-0.405858 \quad 3.278585$

$\mathrm{H}-4.1247522 .6388861 .021555$

H -3.882670 $0.868033 \quad 1.136610$

H -3.635454 1.8975922 .577285

H -2.091934 4.0225410 .979955

H -1.672295 3.3361082 .580673

H -0.533426 $3.161610 \quad 1.224521$

H -3.113930 $-2.845412-0.477447$

H -2.877633 $-2.173011 \quad 1.169226$

H -4.392064 $-1.834600 \quad 0.260503$

H - 2.927251 $-1.261333-2.335138$

$\mathrm{H}-4.182770-0.215052-1.611885$

$\mathrm{H}-2.536087 \quad 0.428845-1.912693$

H $1.602209-0.875528-0.608580$

H $0.056579-1.678406-1.003020$

H $1.000145-0.879858-2.297990$

H $1.5608691 .616276-0.562607$

H $1.068241 \quad 1.530055-2.291174$

H $0.0420852 .382660-1.104640$

36

param $=79.830299 \mathrm{E}=-590.007803$

C $-0.847924-1.0024102 .589929$

C $0.465307-0.501636 \quad 2.386734$

C $0.956781 \quad 0.784673 \quad 2.506638$

Li $-1.160967 \quad 0.176658 \quad 0.798509$

O - $2.173658 \quad 1.945943 \quad 1.075379$

C $-1.5718853 .162881 \quad 1.514383$

C $-3.549368 \quad 1.863855 \quad 1.439422$

$\begin{array}{llll}\text { O }-0.054016 & 0.339459 & -0.961050\end{array}$

C $0.6955421 .524619-1.219527$

C $0.697540-0.843747-1.228155$

O - $2.706074-0.822198-0.330344$

C $-3.355700-1.978467 \quad 0.193629$

C -3.138621 $-0.484701-1.641949$

H $1.998676 \quad 1.0049692 .293821$

H $0.391148 \quad 1.5586793 .022633$

H $1.169753-1.2287051 .965524$

H $-0.961996-2.0833502 .660783$

H - $1.511745 \quad-0.443056 \quad 3.256917$

H -4.116758 $2.692516 \quad 0.992844$ 
$\mathrm{H}-3.9233720 .9134551 .059595$

$\mathrm{H}-3.663313 \quad 1.8942282 .531265$ H -2.040016 4.0221131 .013449 H - 1.6746773 .2767452 .601453 H - $0.5120513 .107767 \quad 1.266632$ H $-3.167252 \quad-2.851370-0.447426$ $\mathrm{H}-2.930449 \quad-2.1455501 .183857$ $\mathrm{H}-4.441345 \quad-1.8166550 .264812$ H -2.960709 $-1.315898 \quad-2.339384$ H $-4.210797 \quad-0.239196-1.651861$ H -2.556519 $0.381309-1.958292$ H $1.594143-0.886132-0.597311$ H $0.052125-1.692206-0.995959$ H $0.990701-0.880106-2.286628$ H $1.5411231 .607042-0.525552$ H $1.0575321 .529082-2.257263$ H $0.0215772 .370157 \quad-1.071074$ 36

param $=84.830299 \mathrm{E}=-590.008108$ C $-0.773562 \quad-0.7761092 .642228$ C $0.577748 \quad-0.505722 \quad 2.262351$ C $1.360622 \quad 0.6149332 .430259$ Li $-1.286728 \quad 0.157381 \quad 0.742984$ O -2.146160 2.0123350 .938859 C-1.630161 2.803857 2.012939 C -3.541023 2.2092990 .739391 $\begin{array}{llll}\mathrm{O} & -0.168246 & 0.438380 & -0.972160\end{array}$ C $0.4655581 .711214-1.121883$ C $0.692204-0.638525-1.340554$ O $-2.738392 \quad-0.947683-0.251611$ C -3.487964 -1.912986 0.486293 C -3.073036 $-0.917575-1.633665$ H 2.3763610 .6500772 .047157 H $1.0632391 .428567 \quad 3.089545$ H $1.047538-1.3067991 .677715$ H - $1.040665-1.8316622 .720875$ H -1.197224 $-0.166572 \quad 3.446748$ H -3.751749 $3.260570 \quad 0.498854$ H -3.843763 $1.575599-0.094959$ $\mathrm{H}-4.108571 \quad 1.924848 \quad 1.636318$ H - $1.7718753 .872188 \quad 1.799158$ H -2.132163 2.548309 2.954671 H - 0.5673012 .5729602 .096277 $\mathrm{H}-3.328411 \quad-2.919505 \quad 0.075418$ $\mathrm{H}-3.119743 \quad-1.870313 \quad 1.511658$ $\mathrm{H}-4.560969 \quad-1.6765790 .453694$ H -2.897170 $-1.897684-2.099396$ $\mathrm{H}-4.128802 \quad-0.644569-1.776756$ H -2.428733 $-0.171779-2.101121$ H $1.599483-0.639099-0.724805$ H $0.140295-1.565111-1.172040$
H $0.967156-0.562147 \quad-2.401777$

H $1.3155491 .795939-0.433648$ H $0.8010081 .848799-2.159170$ H -0.281616 $2.465931-0.873418$ 36

param $=89.830299 \mathrm{E}=-590.008466$ C - $0.689724-0.7916592 .551550$

C $0.666424-0.4177652 .272912$

C 1.3798090 .7115112 .597643

Li - $1.320070 \quad 0.142564 \quad 0.704420$

$\begin{array}{llll}\text { O }-2.156429 & 1.999652 & 0.915076\end{array}$

C - 1.6328002 .7539352 .013217

C -3.537929 2.2499560 .689413

$\begin{array}{llll}\text { O }-0.173045 & 0.417819 & -0.975436\end{array}$

C $0.4924321 .675849-1.114026$

C $0.653068-0.677455-1.366351$

O $-2.780496-0.947167 \quad-0.255767$

C -3.508684 -1.9157880 .498939$

C $-3.145515-0.915202-1.629735$

H $2.407467 \quad 0.839587 \quad 2.269994$

H 1.0020041 .4448283 .308279

H $1.207828-1.1326231 .640440$

H - $0.881512 \quad-1.867942 \quad 2.547589$

H - $1.171206 \quad-0.2854453 .395476$

H -3.706736 3.3123410 .465068

$\mathrm{H}-3.844993 \quad 1.643793 \quad-0.163855$

H -4.135295 $1.969381 \quad 1.568157$

$\mathrm{H}-1.7256973 .830008 \quad 1.811777$

$\mathrm{H}-2.1682662 .5067272 .938685$

H -0.5821952 .4775042 .118753$

H -3.357736 -2.9209960 .081923$

H -3.114364 -1.876109 1.514716

$\mathrm{H}-4.582416-1.681073 \quad 0.495308$

H $-2.977737-1.893811 \quad-2.101418$

H $-4.204427-0.643448-1.749348$

H -2.513240 $-0.167197-2.110428$

H $1.570384-0.706651-0.766241$

H $0.080667-1.590939-1.195128$

Н $0.913034-0.599674-2.431210$

H $1.3519031 .730326-0.434774$

H $0.8201981 .820006-2.152811$

H $-0.2319702 .445925 \quad-0.846378$ 36

param $=94.830299 \mathrm{E}=-590.008738$

C - $0.574746 \quad-0.828532 \quad 2.436648$

$\begin{array}{llll}C & 0.758808 & -0.311428 & 2.289833\end{array}$

C 1.3568310 .8053542 .817596

Li $-1.337003 \quad 0.130197 \quad 0.665709$

O - $2.147283 \quad 1.9842520 .907024$

C - 1.6504122 .6950942 .046998

C -3.490006 2.3239750 .588908 
$\begin{array}{llll}\mathrm{O}-0.193703 & 0.403742 & -1.006830\end{array}$

C $0.513713 \quad 1.640362-1.127003$

C $0.589901-0.713868-1.421060$

$\begin{array}{llll}\text { O }-2.819650 & -0.953062 & -0.242803\end{array}$

C -3.509548 $-1.927141 \quad 0.540467$

C $-3.236970-0.924533-1.601518$

H $2.379724 \quad 1.068986 \quad 2.564693$

H $0.880761 \quad 1.3960293 .598890$

H $1.388241 \quad-0.878178 \quad 1.591908$

H $-0.657124 \quad-1.911638 \quad 2.299430$

H - $1.123588-0.4864563 .322007$

H -3.575273 $3.395997 \quad 0.362794$

H -3.775961 $1.743389-0.289380$

H -4.164334 $2.079202 \quad 1.421603$

H - $1.6683193 .776686 \quad 1.854509$

H - $2.2594562 .471725 \quad 2.932436$

$\mathrm{H}-0.625253 \quad 2.357753 \quad 2.215038$

H -3.367024 -2.931286 0.118203

H -3.076358 $-1.885288 \quad 1.540230$

H $-4.584172 \quad-1.700535 \quad 0.579714$

H -3.081400 $-1.902296-2.079080$

H $-4.301018-0.658567 \quad-1.681091$

$\begin{array}{llll}\mathrm{H}-2.628083 & -0.173370 & -2.107398\end{array}$

H $1.507855-0.788555-0.825500$

H $-0.014909-1.608528 \quad-1.263109$

H $0.849372-0.626772-2.485264$

H $1.386293 \quad 1.651045 \quad-0.462583$

H $0.830705 \quad 1.798144 \quad-2.167081$

H - $0.1778762 .428867 \quad-0.828510$ 36

param $=99.830299 \mathrm{E}=-590.008904$

C $-0.460116 \quad-0.862400 \quad 2.303836$

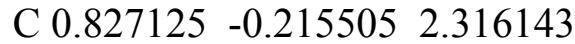

C $1.294435 \quad 0.8386293 .056471$

Li - $1.351467 \quad 0.127363 \quad 0.621575$

O $-2.125710 \quad 1.976542 \quad 0.902463$

C - $1.663145 \quad 2.642785 \quad 2.084343$

C $-3.408529 \quad 2.4205090 .483386$

O - $0.228046 \quad 0.398823-1.063068$

C $0.5009491 .622199-1.181423$

C $0.540241-0.733963-1.466088$

$\begin{array}{llll}\text { O }-2.855239 & -0.962599 & -0.218315\end{array}$

C $-3.492486-1.943823 \quad 0.600044$

C -3.330154 $-0.951110-1.558040$

H $2.292961 \quad 1.237771 \quad 2.903808$

H $0.726335 \quad 1.2485883 .890537$

H $1.534053-0.596305 \quad 1.567603$

H $-0.424320-1.9182332 .009771$

H - $1.060862 \quad-0.721136 \quad 3.211089$

H -3.393464 3.4970940 .263135

H -3.668311 $1.869408-0.422036$
H -4.164620 $2.225355 \quad 1.256954$

H -1.600205 3.7249891 .905337

H -2.346985 2.4517312 .921745

H - $0.673590 \quad 2.2418102 .317932$

$\begin{array}{llll}\mathrm{H}-3.349723 & -2.947923 & 0.177984\end{array}$

H -3.017834 $-1.888556 \quad 1.580107$

$\begin{array}{llll}\mathrm{H}-4.568179 & -1.736121 & 0.684831\end{array}$

H -3.181768 $-1.930703 \quad-2.034130$

H $-4.399780-0.699002-1.594472$

$\begin{array}{llll}\mathrm{H}-2.753225 & -0.197070 & -2.096401\end{array}$

H $1.449385-0.823815-0.858924$

$\mathrm{H}-0.081743-1.617341 \quad-1.312567$

H $0.813867-0.653934-2.527251$

H $1.383319 \quad 1.611697 \quad-0.529622$

H $0.810108 \quad 1.783284-2.223315$

H - $0.1705432 .421729-0.867014$ 36

param $=104.830299 \mathrm{E}=-590.008903$

C $-0.414519-0.834066 \quad 2.237883$

C $0.864782-0.1786712 .363046$

C $1.276273 \quad 0.8270873 .195349$

Li $-1.362703 \quad 0.128317 \quad 0.580566$

O $-2.117440 \quad 1.976191 \quad 0.884962$

C - $1.645396 \quad 2.620147 \quad 2.076058$

C -3.3859902 .4553180 .461616$

O $-0.2540340 .400064-1.114244$

C $0.478990 \quad 1.620975-1.229817$

C $0.523372-0.737823-1.485706$

$\begin{array}{llll}\mathrm{O}-2.869365 & -0.973067 & -0.216143\end{array}$

$\begin{array}{llll}C & -3.479685 & -1.959600 & 0.616262\end{array}$

C $-3.375536-0.964426-1.544578$

H $2.274750 \quad 1.248397 \quad 3.122676$

H $0.654529 \quad 1.1812594 .016760$

H $1.615710-0.5019811 .630221$

H $-0.340847-1.8750441 .897016$

H - $1.054361 \quad-0.759955 \quad 3.127527$

H -3.343606 $3.533083 \quad 0.250736$

H -3.653405 $1.918741 \quad-0.450512$

H $-4.1519342 .272271 \quad 1.228462$

H - 1.5511083 .7014281 .905628

H -2.341951 2.4424882 .905980

H $-0.6698192 .190720 \quad 2.317563$

H -3.336437 $-2.962593 \quad 0.191902$

H -2.986275 $-1.899952 \quad 1.586706$

H -4.555157 $-1.761963 \quad 0.723872$

H -3.232782 $-1.943271-2.023792$

H $-4.446923-0.717914-1.555614$

H -2.815343 $-0.207611 \quad-2.096561$

H $1.414207-0.823834-0.851554$

H $-0.104295-1.618734-1.342136$

H $0.826727 \quad-0.667367 \quad-2.539404$ 


\begin{tabular}{|c|c|}
\hline Н $1.353531 \quad 1.612439-0.567239$ & C $0.468072 \quad 1.612115-1.281867$ \\
\hline Н $0.803098 \quad 1.775510 \quad-2.268108$ & С $0.463828-0.742641-1.562922$ \\
\hline H $-0.194323 \quad 2.424203 \quad-0.928955$ & $\mathrm{O}-2.855074 \quad-1.024113 \quad-0.212501$ \\
\hline 36 & C -3.384429 $-2.042887 \quad 0.637008$ \\
\hline param $=109.830299 E=-590.008710$ & C -3.476367 $-0.976509-1.490737$ \\
\hline C $-0.354840-0.8071612 .163126$ & Н $2.203156 \quad 1.2148943 .540869$ \\
\hline C $0.898296-0.1348682 .417768$ & Н $0.483574 \quad 1.0649344 .213241$ \\
\hline C 1.2277740 .8041383 .355653 & H $1.743919-0.370086 \quad 1.803908$ \\
\hline Li -1.363799 0.1347390 .538489 & H -0.217293 $-1.763486 \quad 1.724054$ \\
\hline O -2.106039 $1.977813 \quad 0.868660$ & H -1.068555 -0.7694132 .961671 \\
\hline C-1.635199 2.6026002 .071089 & H -3.266258 3.6034390 .207470 \\
\hline C -3.352525 $2.495424 \quad 0.425952$ & H -3.650270 $2.007015-0.496251$ \\
\hline O - $0.2809620 .401513-1.175230$ & H -4.128371 $2.379188 \quad 1.185167$ \\
\hline C $0.463674 \quad 1.615750-1.282772$ & H - $1.4506553 .683973 \quad 1.854488$ \\
\hline С $0.495745-0.743756-1.526563$ & H -2.313645 2.474676 2.855837 \\
\hline O -2.869753 $-0.988751 \quad-0.208067$ & H -0.657818 2.1273712 .277920 \\
\hline C -3.446960 $\quad-1.978326 \quad 0.644311$ & H -3.273826 -3.0295920 .167256 \\
\hline C -3.428196 $-0.975066-1.515481$ & H -2.810713 $-2.012829 \quad 1.563524$ \\
\hline Н $2.213211 \quad 1.260267 \quad 3.379238$ & H -4.447333 $-1.858421 \quad 0.845034$ \\
\hline Н $0.543521 \quad 1.073198 \quad 4.159574$ & H -3.375891 $-1.940128 \quad-2.009457$ \\
\hline H $1.698399-0.3730951 .704593$ & H -4.544207 $-0.731997 \quad-1.399454$ \\
\hline H -0.226317 $-1.820986 \quad 1.758777$ & H -2.966712 $-0.202548 \quad-2.067516$ \\
\hline H -1.035527 $-0.824993 \quad 3.026471$ & Н $1.317025-0.858159-0.883185$ \\
\hline H -3.275731 3.5720810 .218907 & H -0.192617 $-1.608392-1.462951$ \\
\hline H -3.620770 $1.969500 \quad-0.492355$ & Н $0.823500 \quad-0.669091 \quad-2.598496$ \\
\hline H -4.136141 $2.333090 \quad 1.179518$ & H $1.302330 \quad 1.572865 \quad-0.570000$ \\
\hline H - 1.5003823 .6802491 .905171 & Н $0.8564391 .765714 \quad-2.297872$ \\
\hline H -2.355016 2.4482802 .885833 & $\mathrm{H}-0.1981202 .432518-1.013101$ \\
\hline H -0.680782 2.1395912 .333473 & 36 \\
\hline H -3.317566 $-2.979990 \quad 0.212586$ & param $=119.830299 \mathrm{E}=-590.007737$ \\
\hline H -2.919257 -1.9201941 .596598 & C -0.276154 -0.706106 2.073593 \\
\hline H -4.518043 $-1.783176 \quad 0.792164$ & C $0.934030 \quad-0.068086 \quad 2.544678$ \\
\hline H -3.307763 $-1.953177 \quad-2.002107$ & C $1.132556 \quad 0.7726923 .601926$ \\
\hline H -4.498163 $-0.724652-1.483081$ & Li-1.370939 $0.157473 \quad 0.471133$ \\
\hline H -2.887676 $-0.219009-2.087816$ & O-2.105954 $1.996254 \quad 0.821387$ \\
\hline Н $1.373133-0.833456-0.874362$ & C-1.610210 2.6037542 .023771 \\
\hline H -0.140765 $-1.619540-1.391486$ & C -3.316464 $2.580227 \quad 0.362253$ \\
\hline Н $0.819757-0.679829-2.574489$ & O -0.340492 $0.424188-1.278685$ \\
\hline Н $1.328965 \quad 1.601290-0.607979$ & C $0.483211 \quad 1.591575-1.299515$ \\
\hline Н $0.804824 \quad 1.765327 \quad-2.316269$ & C $0.381184-0.751009-1.648367$ \\
\hline H -0.206394 $2.425942 \quad-0.993463$ & O -2.822967 $-1.061896-0.205507$ \\
\hline 36 & C -3.303926 $-2.094824 \quad 0.655811$ \\
\hline param $=114.830299 \mathrm{E}=-590.008305$ & C -3.527896 $-0.981598-1.438000$ \\
\hline C $-0.346557 \quad-0.749784 \quad 2.131221$ & Н $2.100965 \quad 1.2259643 .792878$ \\
\hline C $0.910420-0.121717 \quad 2.473737$ & Н $0.346100 \quad 0.972118 \quad 4.329181$ \\
\hline C $1.208823 \quad 0.787532 \quad 3.449045$ & H $1.817006-0.2374591 .915107$ \\
\hline Li - 1.3775690 .1459710 .499849 & H -0.081985 -1.6858801 .610690 \\
\hline O -2.110575 1.9903710 .836679 & H - $1.039962 \quad-0.8146312 .860027$ \\
\hline C -1.605160 2.6102032 .028009 & H -3.179841 $3.651058 \quad 0.155574$ \\
\hline C -3.356375 $2.528281 \quad 0.417002$ & H -3.600683 $2.070205-0.560352$ \\
\hline O -0.303964 $0.411501 \quad-1.220250$ & H -4.117541 $2.461399 \quad 1.105574$ \\
\hline
\end{tabular}


H - $1.4107153 .669833 \quad 1.849038$

H -2.346645 2.500661 2.831757

H $-0.6893192 .087142 \quad 2.301937$

$\begin{array}{llll}\mathrm{H}-3.236570 & -3.071329 & 0.157503\end{array}$

$\mathrm{H}-2.668271-2.090997 \quad 1.541363$

$\mathrm{H}-4.347820 \quad-1.905373 \quad 0.940920$

H -3.470340 $-1.934477-1.982349$

H $-4.585026-0.731251-1.270535$

$\begin{array}{llll}\mathrm{H}-3.051225 & -0.199019 & -2.031273\end{array}$

H $1.212213-0.929659-0.955012$

H - $0.316643-1.587915-1.594176$

$\begin{array}{llll}\mathrm{H} & 0.766405 & -0.657580 & -2.673057\end{array}$

H $1.312523 \quad 1.493185 \quad-0.587572$

H $0.881440 \quad 1.760621 \quad-2.309211$

H $-0.1473102 .431505-1.006064$ 